\title{
Mechanism study of alachlor biodegradation by Paecilomyces marquandii with proteomic and metabolomic methods.
}

Journal of Hazardous Materials 291 (2015) 52-64

http://dx.doi.org/10.1016/j.jhazmat.2015.02.063

Rafał Szewczyk, Adrian Soboń, Mirosława Słaba, Jerzy Długoński

"Department of Biotechnology and Industrial Microbiology, Institute of Microbiology, Biotechnology and Immunology, Faculty of Biology and Environmental Protection, University of Łódź, Banacha 12/16, 90-237 Łódź, Poland, tel. +4842 6354465 , Fax. +4842 6655818 , jdlugo@biol.uni.lodz.pl

\section{Abstract}

Alachlor is a herbicide that is widely used worldwide to protect plant crops against broadleaf weeds and annual grasses. However, due to its endocrine-disrupting activity, its application has been banned in the European Union. As described in our earlier work, Paecilomyces marquandii is a microscopic fungus capable of alachlor removal by $\mathrm{N}$-acetyl oxidation. Our current work employs proteomics and metabolomics to gain a better understanding of alachlor biodegradation by the microscopic fungus $P$. marquandii. The data revealed that the addition of alachlor reduced culture growth and glucose consumption rate. At the same time, the rates of glycolysis and the tricarboxylic acid (TCA) cycle increased during the initial stage of growth, and there was a shift toward the formation of supplementary materials (UDP-glucose/galactose) and reactive oxygen species (ROS) scavengers (ascorbate). Proteomic analysis revealed that the xenobiotic presence resulted in a strong upregulation of enzymes related to energy, sugar metabolism and ROS production. However, the unique overexpression of cyanide hydratase in alachlor-containing cultures may implicate this enzyme as the key protein involved in the alachlor biodegradation pathway. The characterization of $P$. marquandii-mediated alachlor removal in terms of cell structure and function resulted in a deeper insight into microorganism strategy toward xenobiotic biodegradation.

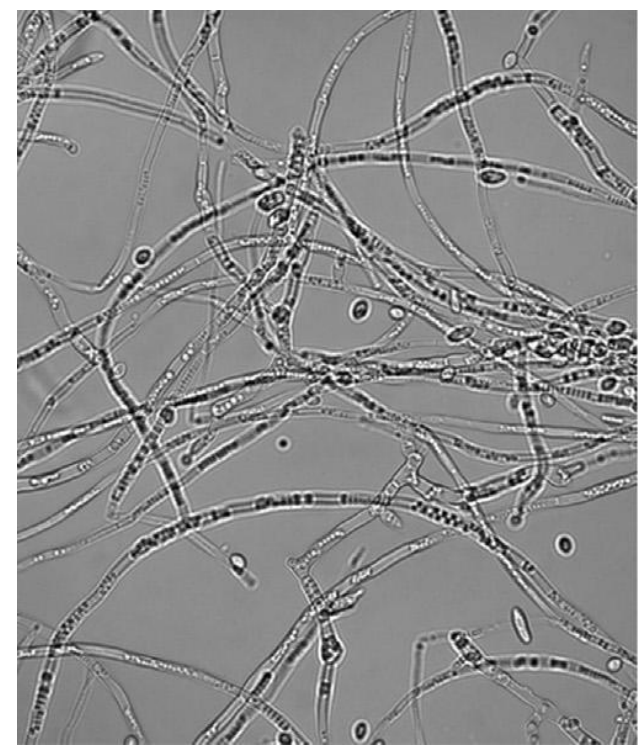

\section{Paecilomyces marquandii}

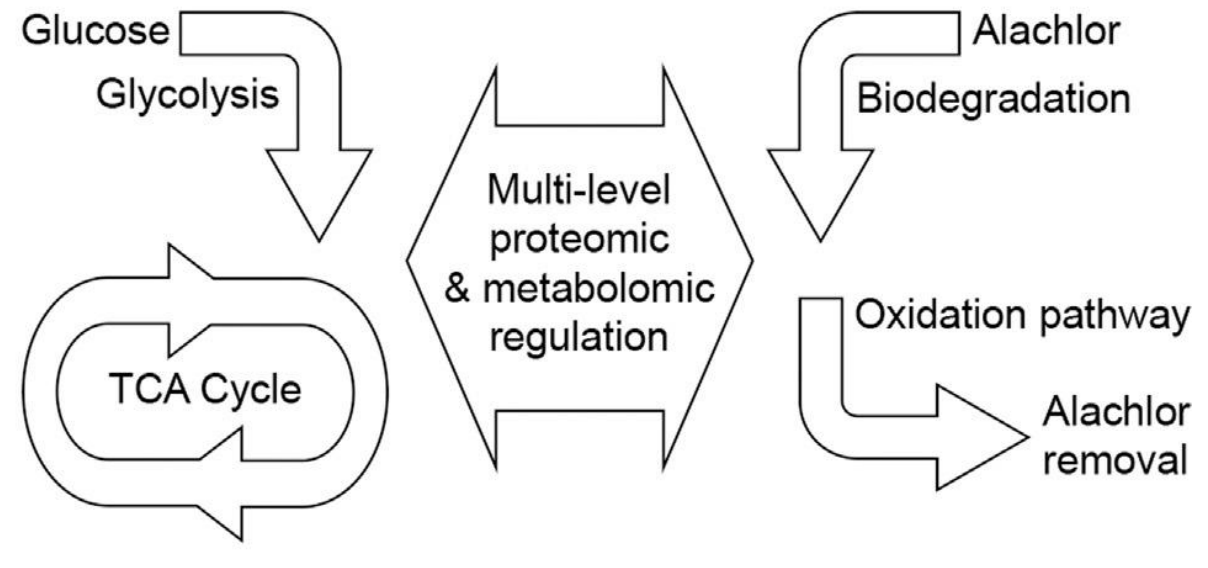

Keywords: fungi, alachlor, biodegradation, proteomics, metabolomics

\section{Introduction}

Alachlor is a pre-emergent chloroacetanilide herbicide that is widely used in world agriculture to protect plant crops (mainly corn) against broadleaf weeds and annual grasses. It is a selective systemic pesticide that interrupts both protein production and the synthesis of long-chain fatty acids in target plants [1,2]. Due to documented endocrine-disrupting activity, alachlor application has banned in the European Union. The risk to animal and human health is amplified by the high water solubility of alachlor $(242 \mathrm{mg} / \mathrm{L})$ and the resultant increased environmental mobility. Alachlor and its metabolites have been detected in soil, water and various biological samples [3]. Some of these intermediates are toxic or mutagenic e.g., 2,6diethylaniline (DEA) $[4,5]$.

Microbial degradation, or rather transformation, plays a pivotal role in the rate of alachlor elimination from the environment [6-8]. There are many studies concerning the both the characterization of selected microbial consortium or microorganisms in pure culture capable of degrading alachlor and the identification of byproducts, but little is known about the molecular mechanisms of conversions.

Proteomics and metabolomics are modern and convenient tools, which have been successfully applied to gain a better understanding of the biodegradation mechanisms in different types of organisms e.g., bacterial biodegradation of insecticide $N$-methylcarbamate by Burkholderia sp. C3 [9] or phenanthrene by Sinorhizobium sp. C4 [10]; fungal degradation of nonylphenol by Metarhizium robertsii [11]; Mucor plumbeus response to pentachlorophenol [12]; or benzoic acid removal by Phanerochaete chrysosporium [13]. Proteomic analysis has also been successfully applied to explore the plant phytoremediation mechanism of pyrene by Scirpus triqueter [14] or in the study of algae Anabaena sp. adaptations under butachlor pesticide action [15]

In our earlier work, $\mathrm{N}$-acetyl oxidation was documented as the primary route of alachlor transformation by the microscopic filamentous fungus $P$. marquandii IM 6003. The possible metabolic pathway was also formulated [16]. In the present study, we elucidated the proteomic background of alachlor biodegradation as well as the changes in the primary sugar metabolism of fungus exposed to herbicide. To our knowledge, this is the first study on alachlor that employs microbial proteome expression in conjunction with multi-compound sugar metabolism research.

\section{Materials and methods}

\subsection{Microorganism and culture conditions}

Paecilomyces marquandii (S. Hughes, 1951), basionym: Verticillium marquandii (Massee, 1898), an alachlor-degrading filamentous fungus [16] from the collection of the Department of Industrial Microbiology and Biotechnology, University of Lodz (identification number: IM 6003) was examined in this work. This strain was selected from post-flotation dumps of non-ferrous metal works (Silesia, Poland) that were strongly polluted with heavy metals [17]. Applied culture conditions were the same as described previously [16].

\subsection{Chemicals}


Ethyl acetate and the ethanol needed for sample extractions and the high purity solvents used during sample preparation for LC-MS/MS analysis were purchased from Avantor (Poland). Alachlor, PESTANAL ${ }^{\circledR}$, analytical standard $(99.2 \%)$ and glucose standard were purchased from Sigma-Aldrich (Germany). All other chemicals and ingredients used in LC-MS/MS analysis, protein sample preparation and MALDI-TOF/TOF analysis were of high purity grade and obtained from Sigma-Aldrich (Germany), Serva (Germany), GEHealthcare (Germany), Avantor (Poland), Promega (USA) or AB Sciex (USA).

\subsection{Alachlor sample preparation}

Following separation by filtration on Whatman 1 (Sigma, Germany), the mycelium was homogenized and extracted with ethyl acetate according to the procedures described previously [16].

\subsection{Glucose metabolism sample preparation}

Sample preparation was modified from a procedure developed by Wei et al. [18]. The filtration-separated mycelium was washed with water and weighed. The mycelium was then divided into 3 portions of $100 \mathrm{mg}$ each and placed into 2-ml Eppendorf tubes containing 1 $\mathrm{ml}$ of cold water. Sections were then homogenized with a glass matrix (diameter $1 \mathrm{~mm}, 4^{\circ} \mathrm{C}$ ) on FastPrep24 (MP Biomedicals, USA) three times for $30 \mathrm{~s}$, with a velocity of $4 \mathrm{~m} \mathrm{~s}^{-1}$ and a 2 min brake for sample cooling on ice. The samples were then centrifuged at 4000 $\mathrm{g}, 4^{\circ} \mathrm{C}$ for $10 \mathrm{~min} .100 \mu \mathrm{l}$ of supernatant was transferred to separate $1.5-\mathrm{ml}$ Eppendorf tubes containing $900 \mu \mathrm{l}$ of $0.1 \%$ formic acid in ethanol and vortexed for 2-3 min. The samples were then incubated for $2 \mathrm{~h},-20^{\circ} \mathrm{C}$ and centrifuged at $14000 \mathrm{~g}, 4^{\circ} \mathrm{C}$ for $20 \mathrm{~min}$. The supernatant was transferred to a new $1.5-\mathrm{ml}$ Eppendorf tube, evaporated until dry at $30^{\circ} \mathrm{C}$ under a vacuum and stored at $-20^{\circ} \mathrm{C}$ for future analysis. Frozen samples were thawed at $4^{\circ} \mathrm{C}$ for $30 \mathrm{~min}$ followed by $15 \mathrm{~min}$ at room temperature, resuspension in $1 \mathrm{ml}$ of water:acetonitrile (ACN) 98:2 (v/v), sonication and vortexing for 2 $\min$ and incubation for $60 \mathrm{~min}$ in $4^{\circ} \mathrm{C}$. Finally, the samples were transferred to a 96 -well plate for LC-MS/MS analysis.

2.5. LC-MS/MS qualitative and quantitative trend analysis and screening

The qualitative and quantitative LC-MS/MS analysis of alachlor biodegradation and glucose concentration was conducted with Agilent $1200 \mathrm{HPLC}$, coupled with AB Sciex 3200 QTRAP mass spectrometer according to methods developed previously $[16,19]$. A trend analysis of the alachlor metabolites was performed on the basis of precursor ion $162.1 \mathrm{~m} / \mathrm{z}$-extracted ion chromatograms, covering a scan range of 160 to $320 \mathrm{~m} / \mathrm{z}$ [16].

The LC-MS/MS screening method applied for the glucose metabolism investigation was based on a multi-method developed by Wei et al. [18]. An AB Sciex 4500 QTRAP mass spectrometer (AB Sciex, USA), coupled with an Eksigent microLC 200 System (Eksigent, USA) were employed for analysis. Chromatography separation was conducted on an Eksigent C18-AQ (0.5 mm x 150 $\mathrm{mm} \times 3 \mu \mathrm{m}, 120 \AA$ ) column: temperature $35^{\circ} \mathrm{C}$, injection volume $5 \mu \mathrm{l}$ on the column. The eluent consisted of $2 \mathrm{mM}$ of ammonium formate and $0.1 \%$ of formic acid in water $(A)$ and $A C N(B)$. The gradient used had a constant flow of $50 \mu \mathrm{l} \mathrm{min}{ }^{-1}$ with $0.5 \mathrm{~min}$ of preflush conditioning, followed by $0.1 \mathrm{~min}$ in which $98 \%$ of eluent $\mathrm{A}$ was used and then a decrease to $2 \%$ of eluent $A$ for minutes 2.5-3.4. Initial conditions were restored from 3.5-4.0 min. The MS/MS detection was made in negative and positive ionization in multiple reactionmonitoring (MRM) mode. The optimized microESI ions source parameters were as follows: CUR: 25 ; IS: $-4500 \mathrm{~V}$; TEMP: $300^{\circ} \mathrm{C}$; GS1: 30; GS2:30 and ihe:ON. Compound-dependent MRM parameters are presented in table S-1.

\section{6. $P C A$ analysis}

Principle Component Analysis (PCA) was prepared with the MarkerView ${ }^{\mathrm{TM}}$ software (AB Sciex, USA) on MRM data (chromatography peak areas) from microLC-MS/MS analysis, with retention time locking in. After data set normalization against maximum and minimum values within the data set, the Pareto algorithm was applied for PCA calculation. Excel 2007 (Microsoft Corporation, USA) was used to report PCA loadings in the form of a heat map.

\subsection{Protein extraction}

Proteins from the mycelium were extracted with the use of mechanical homogenization on FastPrep24 (MP Biomedicals, USA) with glass beads (1-mm diameter), followed by TCA precipitation as described previously [11].

\subsection{2-D electrophoresis}

Total protein content was measured using the Bradford method, with BSA (Sigma, Germany) as the protein standard. 2-D electrophoresis was conducted according to the procedure described previously [11] with modifications. Mycelial protein samples $(500 \mu \mathrm{g})$ were loaded in $13 \mathrm{~cm}$ nonlinear IPG strips, pH 3-11 (GE Healthcare, Germany). Isoelectric focusing (IEF) was performed as follows: $60 \mathrm{~V}$ for $1 \mathrm{~h}$, $120 \mathrm{~V}$ for $30 \mathrm{~min}, 150,300$ and $600 \mathrm{~V}$ (each for $1 \mathrm{~h}$ ), $1500 \mathrm{~V}$ for 20 h, $1800,2100,2400$ and $2700 \mathrm{~V}$ (each for $30 \mathrm{~min}$ ), $3000 \mathrm{~V}$ for $44 \mathrm{~h}$, $3300,3600,3900,4100,4400,4700$ and finally $5000 \mathrm{~V}$ (each for 1 h). The second dimension was performed using a $12 \%$ running gel with a stacking gel on the top. The separation was run at $100 \mathrm{~V}$ for the stacking gel and $220 \mathrm{~V}$ for the running gel (Hoefer, USA). A molecular mass standard covering the range of $6.5-200 \mathrm{kDa}$ (Sigma, Germany) was used. Gels were stained with Coomassie blue. Comparative and statistical analysis of the gel triplicates was performed using Image Master 2D Platinum 7 software (GE Healthcare, Germany) and included automatic alignment of the gels, spot detection and measurement, background subtraction and subsequent normalization. After manual correction of mismatches within the data, spots with a p-value $<0.05$ (and volume $>0.5$ ) were considered to be significant.

\subsection{Protein digestion}

Protein digestion with trypsin was performed according to the procedure described previously [11].

\subsection{MALDI-TOF/TOF analysis}

AB Sciex 5800 TOF/TOF system (AB Sciex, USA) was used for data acquisition. Samples were placed on the MALDI plate twice, to cover the selection of the 25 strongest precursors for MS/MS analysis. The TOF MS analysis was conducted in the mass range of 800-4000 Da, $2400 \mathrm{~V} / 400 \mathrm{~Hz}$ laser relative energy, 2000 shots per sample and with the precursor selection order set from strongest to weakest. The instrument was externally calibrated in TOF MS mode with a peptide mixture (AB Sciex, USA) covering the tested mass range. The TOF/TOF MS/MS analysis was conducted in the mass range from $10-4000 \mathrm{Da}, 3300 \mathrm{~V} / 400 \mathrm{~Hz}$ relative laser power, CID gas (air) at a pressure of ca $5 \times 10^{-7}$ and up to 4000 shots per precursor with a dynamic exit. The precursor selection was set from the weakest to strongest in this mode. The external calibration of MS/MS mode with the fragments of Glu-fibrinopeptide (AB Sciex, USA) $(1570.677 \mathrm{~m} / \mathrm{z}$ ) was applied.

\subsection{Protein homology identification and functional alignment}

Protein Pilot v4.5 software (AB Sciex, USA), coupled with Mascot search engine v2.4 [20] was used for initial database searches. The data were searched against the NCBI non-redundant database (version 05.2014; total number of sequences 38633935 ), with the taxonomy filtering the set to fungi (total number of fungi sequences 4 679 025). Mascot MS/MS ion searches were performed with trypsin chosen as the protein digesting enzyme, up to two missed cleavages were tolerated and the following variable modifications were applied: Acetyl (N-term), Carbamidomethyl (C), Deamidated (NQ), Gln to pyro-Glu (N-term Q), Glu to pyro-Glu (N-term E), Oxidation (M). Searches were conducted with a peptide mass tolerance of $50 \mathrm{ppm}$ and a fragment ion mass tolerance of $0.3 \mathrm{Da}$.

Proteins identified and unidentified by MASCOT searches were further processed using a BLAST $[21,22]$ search against the NCBI non-redundant protein sequences database (total number of sequences 38633 935), with the use of the DELTA-BLAST algorithm (Domain Enhanced Lookup Time Accelerated BLAST) to confirm or define the probable function of the protein. The data for the BLAST searches derived from either Mascot results or, in the case of proteins unidentifiable by Mascot, were built on the basis of the set of single spot peptide sequences, manually evaluated with 


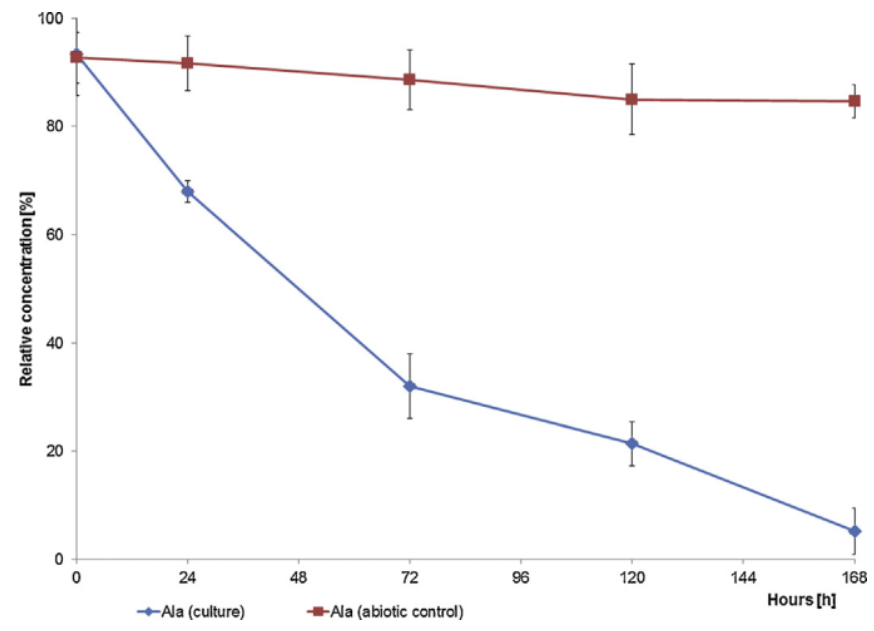

Fig. 1. Alachlor $(50 \mathrm{mg} \mathrm{L}-1)$ biodegradation by Paecilomyces marquandii on Sabouraud medium 3.1. Alachlor biodegradation

the use Data Explorer (AB Sciex, USA) and PeakView software with a Biotools plugin (AB Sciex, USA).

\section{Results and discussion}

As was shown previously [16], the tested strain is capable of efficient alachlor removal at the concentration of $50 \mathrm{mg} \mathrm{L}^{-1}$. The degradation pathway included 10 metabolites formed by dechlorination and oxidation reactions of 2-chloro- $\mathrm{N}$-(methoxymethyl)acetamide substituent. In the current work, we did not find any new metabolites using the applied LC-MS/MS method, and we therefore focused on the repeatability of alachlor removal as well as the repeatability of the trend analysis of alachlor derivatives. Analysis of replicates indicated that, in the case of alachlor removal, the standard deviation (SD) ranged from $2 \%-11 \%$, while the trend analysis SDs were in the range of $6 \%-22 \%$. The results demonstrated that the biodegradation course is reproducible in applied culture conditions, and the biodegradation curves are very similar to the ones published previously [16]. According to the data obtained from separate homogenized mycelium and culture medium extractions, removal of the xenobiotic takes place inside the cells of the tested strain. Alachlor removal and metabolite formation curves were used to determine the best time periods for intracellular proteome expression studies. Alachlor removal starts immediately; after the first $72 \mathrm{~h}$, only $32 \%$ of alachlor is still present in the culture. After $168 \mathrm{~h}, 95 \%$ of the substrate is removed (Fig 1). On the other hand, the majority of the tested metabolites reached their relative concentration maximum after $120 \mathrm{~h}$ (Fig. 2). The data suggested that the $120 \mathrm{~h}$ cultures are best suited for comparative proteomic studies.

\subsection{Glucose cometabolism}

Metabolomics is a new system biology tool that has been employed in various scientific applications including medicinal chemistry, plant physiology and microbiology. However, the metabolomics of biodegradation is a completely new approach in this field. It comprehensively analyzes low molecular weight metabolites, including intermediates, and may include numerous primary and secondary metabolites [23].

Generating growth curves is essential for the metabolomic research of microbial cultures. The dry weight curves (Fig. 3) revealed that intensive growth in control cultures lasted until $96 \mathrm{~h}$, whereas in alachlor-containing cultures, this phase ends after $120 \mathrm{~h}$. Maximum growth is reached in both cultures after $144 \mathrm{~h}$ of culturing. However, the growth of alachlor-containing cultures is inhibited and reached $9.75 \mathrm{~g} \mathrm{~L}^{-1}$ in comparison to control cultures, where $11.51 \mathrm{~g} \mathrm{~L}^{-1}$ of dry weight was measured.

Glucose uptake reflects the growth potential of a strain under the tested conditions. A rapid decrease in concentration was observed in the cultures during the first $72 \mathrm{~h}$ of the experiment, but, as is demonstrated in Fig. 4, substrate depletion occurs more rapidly in the control cultures, where after $72 \mathrm{~h}, 7.33 \%$ of the glucose remained while in the alachlor-containing cultures, $20 \%$ of the glucose was detected. After $168 \mathrm{~h}$ in culture, glucose was completely absent from the control cultures, which was in contrast with xenobiotic-supplemented cultures, which still contained 5.15\% of the substrate.

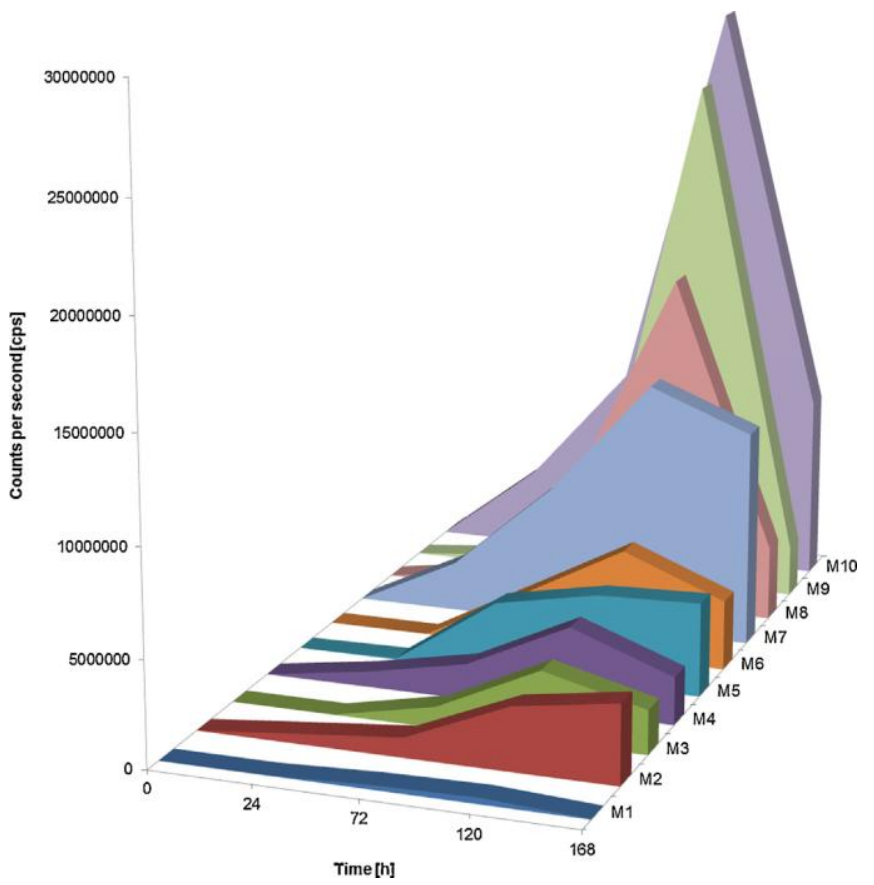

Fig. 2. Trend analysis of the identified metabolites duringalachlor (50 $\mathrm{mg} \mathrm{L-1)}$ biodegradation by Paecilomyces marquandiion Sabouraud medium. Abbreviations means: M1 - N-[2-ethyl-6-(2hydroxyethyl)phenyl]-N-(methoxymethyl)acetamide; M2-2,6-diethyl$\mathrm{N}$-methylaniline; M3 - M N-(2,6-diethylphenyl)- $\mathrm{N}$ [(dihydroxymethoxy)methyl]-2-hydroxy-2-methoxyacetamide; M4 -N(2,6-diethylphenyl)-2,2-dihydroxy- $\mathrm{N}$ -

[(hydroxymethoxy)methyl]acetamide;M5 - N-(2,6-diethylphenyl)-2,2dihydroxy-N-(methoxymethyl)acetamide; M6- (Z)-1-[(2,6diethylphenyl)(methoxymethyl)amino]ethene-1,2-diol; M7 -N-(2,6diethylphenyl)-2-hydroxy- $\mathrm{N}$-(methoxymethyl)acetamide; $\mathrm{M} 8$ - N-(2,6diethylphenyl)- $\mathrm{N}$-[(dihydroxymethoxy)methyl]-2-methoxyacetamide; M9 -\{(2,6-diethylphenyl)[(hydroxymethoxy)methyl]amino\}(oxo)acetic acid; M10-N-(2,6-diethylphenyl)-N-(methoxymethyl) acetamide.

Further insight into carbon source usage in the presence of the xenobiotic, was achieved by focusing on sugar metabolism. Therefore, this research primarily focused on glucose (glycolysis, TCA cycle) or glucose metabolism-related compounds, and it included 32 compounds analyzed in MRM mode on a microLCMS/MS instrument. The applied LC-MS/MS method and sample preparation procedure was developed on the basis of a multi-method developed by Wei et al. [18] and modified for use with mycelia material extraction and analysis. The LC-MS/MS data from the control (c) and alachlor-containing (ala) cultures were subjected to principal component analysis (PCA) [24] with the use MarkerView software (AB Sciex, USA). The major differences occurred during the first $24 \mathrm{~h}$ of culture, as is presented in Fig.5, where samples $0 \mathrm{~h}$ and ala 24 are located on the PCA chart at the longest distances between both each other and the rest of the samples. The location of the samples on the chart is most affected by the high amounts of methylmalonate/succinate and UDP-glucose (samples ala 24), malate and aconitate (samples $0 \mathrm{~h}$ ) and citrate (the rest of the samples) (Fig.5). Notable variation is also observed within the other samples, and sample groups c 24 , ala 72 , ala 120 \& ala 168 and $c$ 120 \& c 168 tend to formulate clusters in different locations as compared to each other. To examine all data, PCA loadings for each analyte (peak areas) were averaged and recalculated to percentage values ( $100 \%$ is the highest loading for the analyte). The data are presented in Table 1, where the heat map and the simple chart scoring were applied to facilitate data evaluation. The data revealed a significant increase in the relative concentrations reaching the maximum or a high level of the selected compounds after $24 \mathrm{~h}$ of culturing in alachlor-containing cultures, especially hexose monoand diphosphates, glycerol/glycerate group and end products of the TCA cycle (succinate, fumarate, malate, oxaloacetate). Similar behavior was observed for Acetyl-CoA. However, the citrate concentration was lower after $24 \mathrm{~h}$ in alachlor-containing cultures in comparison to control samples. On the other hand, citrate concentrations in both cultures were similar in all other tested time points. The maximum relative concentration in ala 24 samples was also observed for UDP-glucose/galactose, which is significant 


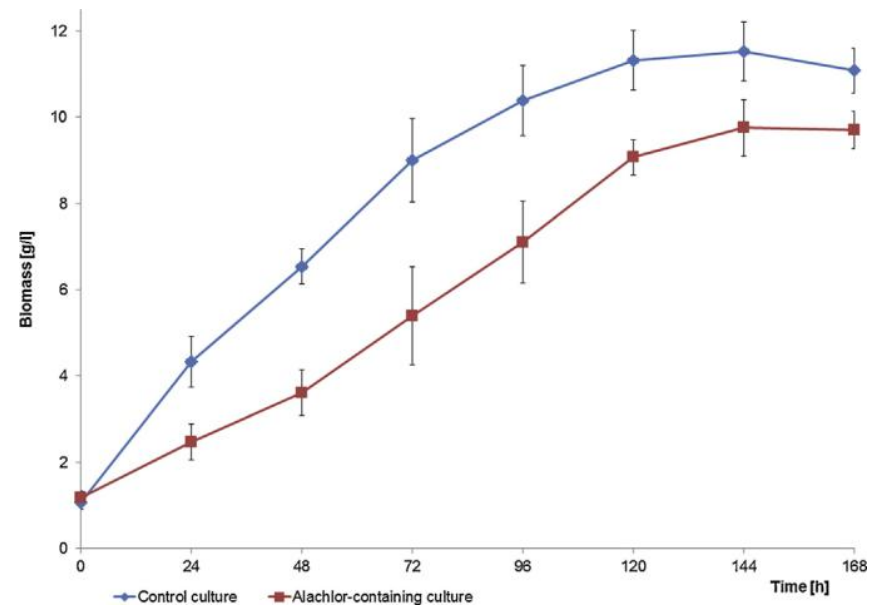

Fig. 3. Dry weight of the alachlor-containing (50 mg L-1) and control cultures of Paecilomyces marquandii on Sabouraud medium.

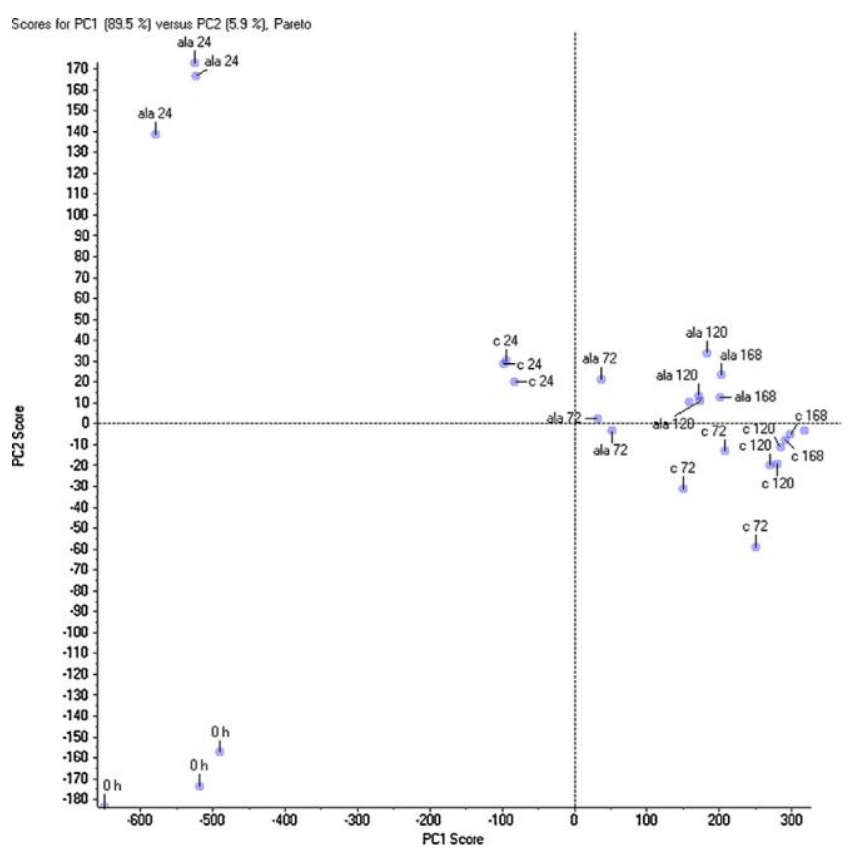

Fig. 5. PCA of the mycelial glucose metabolism on alachlorcontaining (50 mg L-1) and control cultures on Sabouraud medium. On the left - PC1 against PC2 loadings chart;on the right - PC1 against PC2 scores chart.

Table 1. Relative concentration of the monitored compounds during alachlor $(50 \mathrm{mg} \mathrm{L}-1)$ biodegradation by Paecilomyces marquandii on Sabouraud medium.

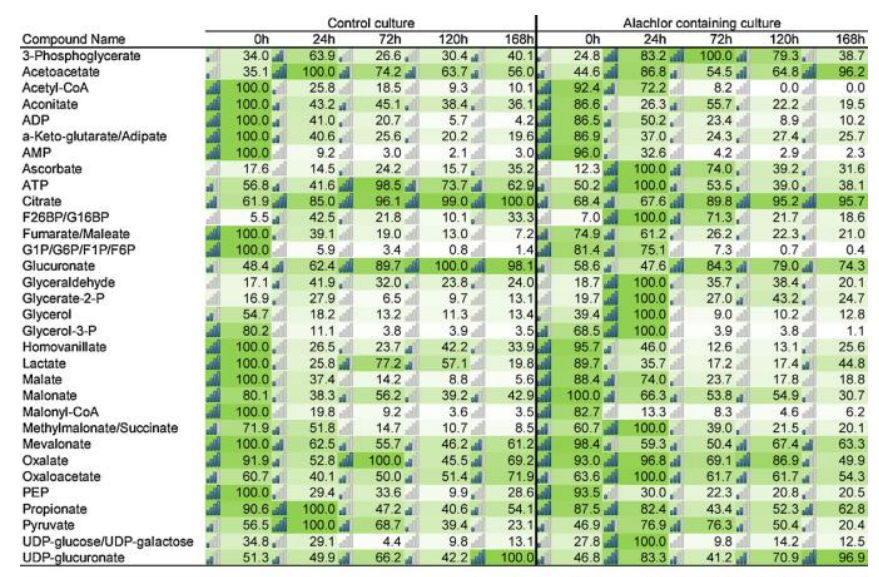

Legend: Af 20.0 a 40.0 all 60.0 in 80.0 all 100.0

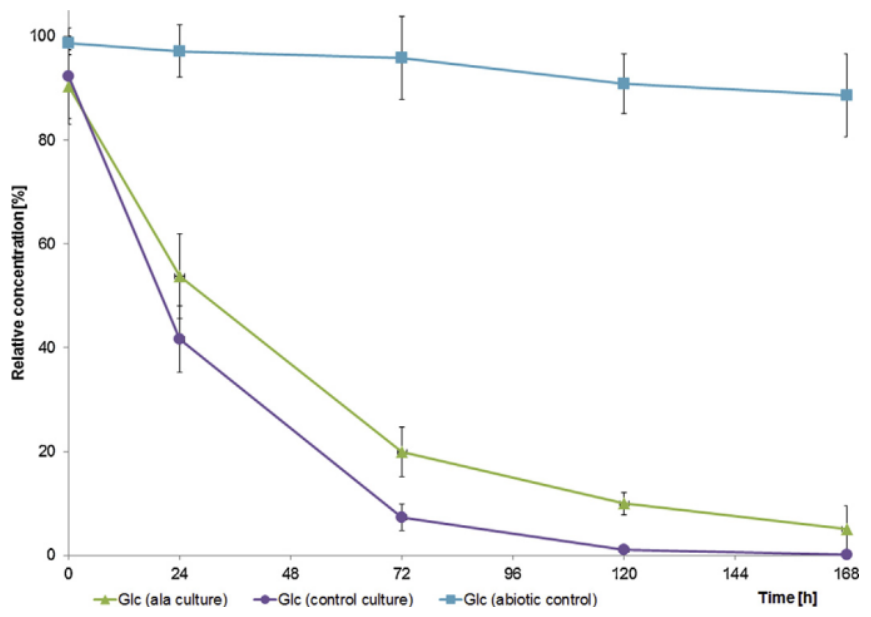

Fig. 4. Glucose consumption on alachlor-containing ( $50 \mathrm{mg} \mathrm{L}-1)$ and control cul-tures of Paecilomyces marquandii on Sabouraud medium.

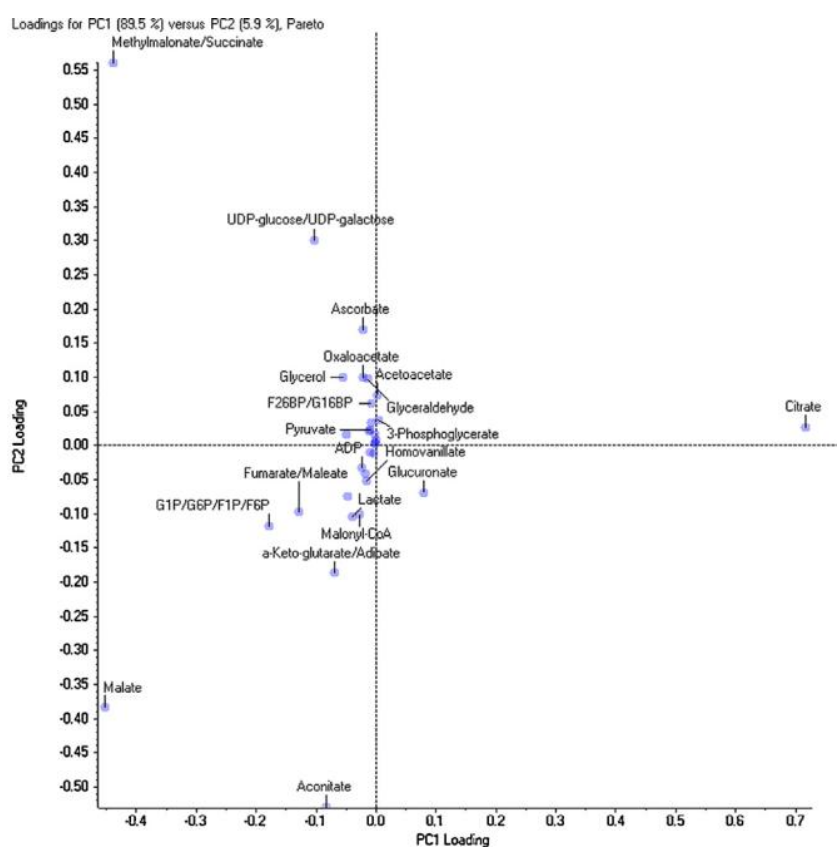

because in all other samples, the relative concentration was lower by $70-90 \%$. Interestingly, ascorbate and 3-phosphoglycerate concentrations significantly increased in ala 24 , ala 72 and ala 120 samples in comparison to the other samples.

Metabolomic analyses of the white-rot fungus $P$. chrysosporium exposed to benzoic acid (BA) included various compounds such as glycolysis intermediates, TCA cycle intermediates, amino acids and lipids [13] determined by the untargeted GC-MS method. It was found that to effectively metabolize BA, fungal regulation of the TCA cycle and mannitol cycles as well as the regulation and utilization of trehalose as a storage sugar were observed. In the case of TCA cycle metabolites, the majority of the compound concentrations decreased in the presence of BA. Similarly, the few glycolysis intermediates (ex. glucose, glucose-6-phosphate, glycerol-3phosphate) also decreased in concentration or stayed at the same level, contrary to the results obtained in this work. A comprehensive metabolomic study on bacterium Sinorhizobium sp. C4 during the degradation of phenanthrene [10] also included numerous compounds measured using the untargeted GC-MS method. Among the other compounds, the differential study also included organic acids, glycolysis and TCA cycle metabolites. In general, a higher accumulation of some intermediates from glycolysis (e.g., 2phosphoglycerate), the TCA cycle (e.g., oxalate) and others (2hydroxyglutarate, malonate and 3-hydroxyisovalerate) were found in the phenanthrene-supplemented culture, with a parallel reduction in the level of other metabolites in the same pathway (e.g., 3phosphoglycerate, malate and a-ketoglutarate).

In summary, the addition of alachlor drives the source of carbon metabolism towards higher and more efficient consumption during 

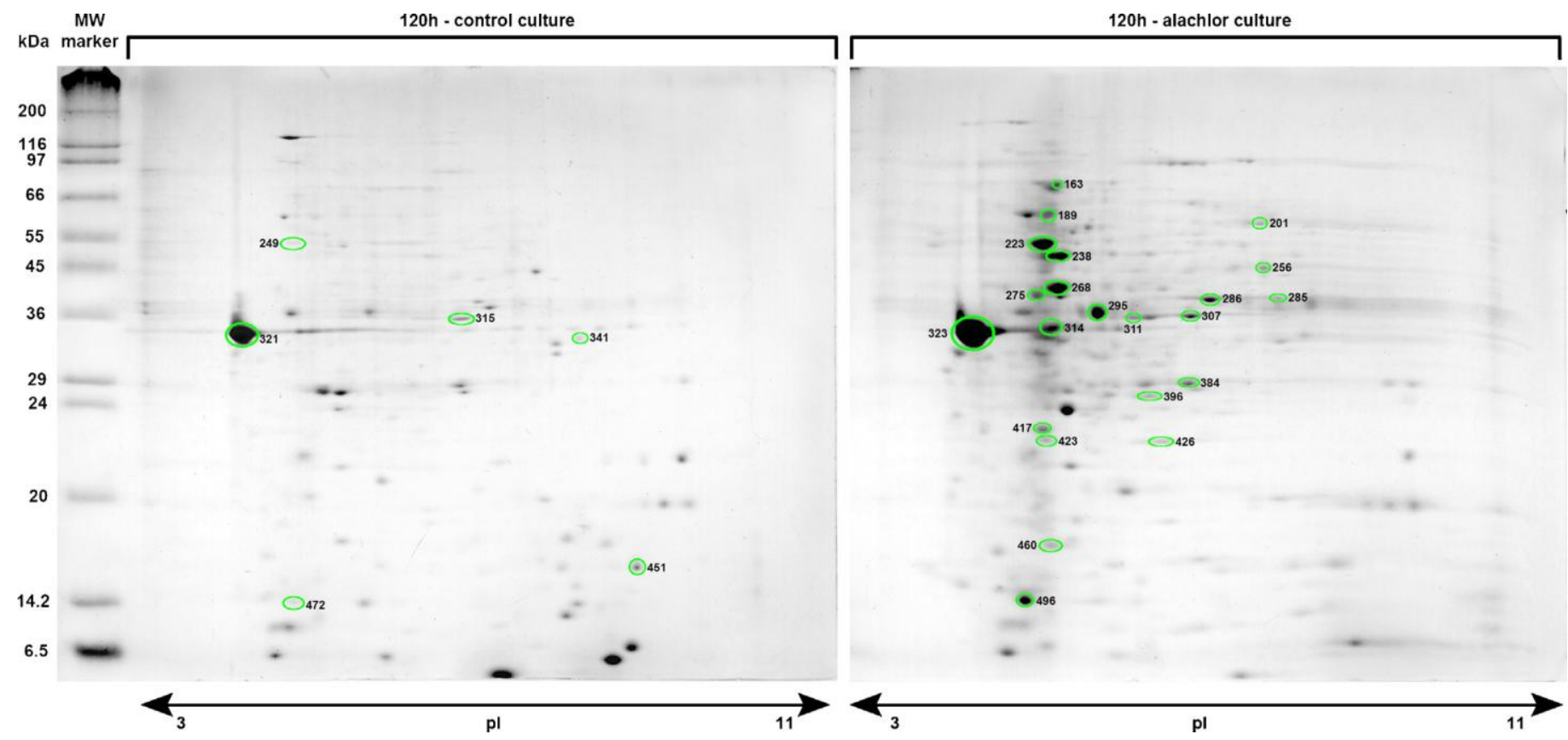

Fig. 6. 2-D electrophoresis gels after $120 \mathrm{~h}$ of Paecilomyces marquandii culture. Marked spots were analyzed and identified by MALDI-TOF/TOF sequencing followed bydatabase searches.

the initial stage of growth (increased glycolysis and TCA cycle rate), but it also changed the glucose utilization to form polysaccharides, supplementary materials, lipopolysaccharides and glycosphingolipids (UDP-glucose/galactose) and ascorbate, which is known to act as a powerful reducing agent, capable of rapidly scavenging a number of reactive oxygen species that may be formed in this case during alachlor biodegradation. The more efficient consumption of glucose, accompanied by the slowdown of growth curves, may be a result of the high-stress conditions in alachlor-containing cultures. However the toxic influence of the xenobiotic may directly affect glucose consumption, growth and the concentration of other compounds involved in intracellular metabolism.

\subsection{Proteomic studies}

Despite the prevalence of these organisms in the various fields of biotechnology, industry, environmental protection and medicine [11,13,25-28], proteomic studies of filamentous fungi are a new trend in the research. To our knowledge, the proteomics (especially intracellular proteomics) of the fungal biodegradation is represented by a very small number of research papers. This paucity of proteomic studies is likely due to the challenge of protein extraction, as this group of microorganisms secrete proteases, display polarized growth, have heavily clustered microtubules organelles and generally possess thick, compact cell walls [29]. The method of protein extraction we developed for $M$. robertsii [11] has been successfully applied to our current work for the extraction of intracellular proteins from $P$. marquandii.

Our data revealed that at $120 \mathrm{~h}$, the cultures are best suited for the comparative proteomics of alachlor biodegradation by $P$. marquandii. Extraction of the intracellular proteome was followed by 2-D electrophoresis separation, revealing the presence of 247 and 265 protein spots in control and alachlor containing samples, respectively (Fig. 6). The gel analysis conducted with ImageMaster 2D Platinum software resulted in the matching of 93 spots and allowed for a comparison of relative expression between the samples on the basis of the percentage of the spot volume quantitation done after total volume normalization within the gels. In the case of unmatched spots, the relative volume of $0.5 \%$ or higher was used as a criterion for the spots excised. Within the matched spots, the fold change analysis was performed, and spots that were characterized by a 2 fold or higher change in up- or down regulation were subjected to spots excision. The applied criteria resulted in the selection of 58 proteins from control cultures and 42 proteins from alachlorcontaining cultures for trypsin digestion, followed by MALDITOF/TOF sequencing.

The proteomic background of gossypol (a derivative of naphthalene) biodegradation by Aspergillus niger AN-1 was investigated by Yang et al. [30] with glucose or gossypol acting as a sole source of carbon in cultures. 478 spots were detected on the glucose gel, whereas 592 spots were detected on the gossypol gel. An average of 293 protein spots were matched on both gels. Through 2-DE analysis, 51 protein spots, which may be related to the biodegradation of gossypol, were differentially expressed between the two carbon sources. A total of 20 spots of interest were identified using MALDITOF MS, where 4 proteins were related to energy metabolism, while 14 proteins were identified as either unnamed or hypothetical proteins from $A$. niger. Whole proteome analysis of PCP biodegradation by $M$. plumbeus revealed the presence of over 700 protein spots in control and PCP-treated cultures [12]. On the basis of the proteins identified, it was demonstrated that exposure to PCP leads to upregulation of several proteins involved in defense mechanisms against stress (e.g., HSP70, cytochrome c peroxidase and thiamine biosynthetic enzymes). However, as the authors stated, none of the mycelial or extracellular proteins found were involved in the PCP biodegradation pathway. This is with the exception of the ADH mycelial protein, which is thought to play an important role in the last steps of PCP degradation. The key step of the biodegradation of $4-n$-nonylphenol $(4-n$-NP) by M. robertsii [11] took place after $24 \mathrm{~h}$ of culturing. 2-DE analysis showed the expression of 205 and 208 protein spots in the control and 4-n-NP supplemented cultures, respectively. 88 spots matched in both gels and were differentially expressed in the cultures. However, the differences were not significant (below 1-fold). The main differences included 14 protein spots present only in control samples and 19 protein spots present only in xenobiotic containing cultures. The identification of selected proteins based on the MALDI-TOF/TOF sequencing of tryptic digests helped explain the proteomic background of $4-n$-NP removal, which involved oxidation-reduction systems, ROS defense systems, the TCA cycle and energy-related systems.

The proteins identified in $P$. marquandii cultures are presented in the Table 2 and 3 , and the full set of the database searches are shown in the tables S-2 and S-3. The homology (Mascot searches) and functional alignments (BLAST searches with the delta-blast algorithm) within the 100 tested protein spots allowed for the identification and/or functional assignment of 28 protein spots, although the tested strain is not sequenced. These included 7 out of 58 selected protein spots in control cultures and 21 out of 42 selected protein spots in the alachlor-containing cultures. In both cultures, the dominant matched spots 321 and 323 have more than one hit in the database including stress protein DDR48 (control culture), N-acetylmuramoyl-L-alanine (ala culture), amidase transcription termination factor Rho and mold-specific protein (both cultures).The possibility cannot be excluded that within a spot of that size more than one protein is located, but regarding further database hits (data not shown) the structural mold-specific protein is the major component of the spot. Both cultures are characterized by the presence of energy-related (ATP synthase) and sugars metabolism enzymes (kinases, transaldolases, reductases, dehydrogenases, mutases and isomerases). However in the alachlor-containing 
Table 2. Summary of Mascot and BLAST search results after $120 \mathrm{~h}$ of the Paecilomyces marquandii control culture. Mascot algorithm matching protein scores greater than 73 aresignificant $(p<0.05)$. Delta-BLAST algorithm - the lower the E-value (closer to zero), the more significant is the match.

\begin{tabular}{|c|c|c|c|c|c|c|c|c|}
\hline \multirow{2}{*}{$\begin{array}{l}\text { Spot } \\
\text { ID. }\end{array}$} & \multicolumn{7}{|c|}{ Mascot search result } & \multirow[t]{2}{*}{ DELTA-BLAST Results } \\
\hline & $\begin{array}{l}\text { Best Protein } \\
\text { Accession }\end{array}$ & $\begin{array}{l}\text { Mass } \\
{[\mathrm{Da}]}\end{array}$ & $\begin{array}{l}\text { Calc. } \\
\text { pl }\end{array}$ & $\begin{array}{l}\text { Peptides } \\
\text { Matched }\end{array}$ & $\begin{array}{l}\text { Seq. } \\
\text { Cov. }\end{array}$ & Score & Best Protein Description & \\
\hline \multirow[t]{3}{*}{$\begin{array}{l}249 / \\
247\end{array}$} & gi|358398002 & 54863 & 5.47 & 31 & $50 \%$ & 194 & $\begin{array}{l}\text { ATP synthase beta chain mitochondrial precursor [Trichoderma } \\
\text { atroviride IMI206040] }\end{array}$ & \multirow{3}{*}{$\begin{array}{l}\text { [cd01133] F1- ATP synthase beta subunit, } \\
\text { nucleotide-binding domain; } E=0 e+00 \\
\text { [cl08258] ATP synthase alpha/beta chain, C- } \\
\text { terminal domain; } E=2.38 \mathrm{e}-33 \\
\text { [cl18399] ATP synthase alpha/beta family, } \\
\text { beta-barrel domain; } E=5.22 \mathrm{e}-19 \\
\text { [PRK09280] F0-F1 ATP synthase subunit } \\
\text { beta; Validated; } E=0 e+00\end{array}$} \\
\hline & gi|400595077 & 55284 & 5.26 & 29 & $45 \%$ & 171 & ATP synthase beta chain [Beauveria bassiana ARSEF2860] & \\
\hline & gi|471567117 & 54831 & 5.46 & 25 & $38 \%$ & 159 & $\begin{array}{l}\text { putative atp synthase beta mitochondrial precursor protein [Eutypalata } \\
\text { UCREL1] }\end{array}$ & \\
\hline \multirow[t]{3}{*}{314} & gi|322697295 & 35337 & 6.49 & 30 & $51 \%$ & 105 & transaldolase [MetarhiziumacridumCQMa102] & \multirow{3}{*}{$\begin{array}{l}\text { [cd00957] transaldolases including both TalA } \\
\text { and TalB; } E=2.63 \mathrm{e}-176 \\
\text { [PTZ00411] transaldolase-like protein; } \\
\text { Provisional; } E=5.88 \mathrm{e}-152\end{array}$} \\
\hline & gi|322712191 & 34600 & 6.86 & 27 & $34 \%$ & 105 & transaldolase [MetarhiziumanisopliaeARSEF23] & \\
\hline & gi|399165577 & 35653 & 5.64 & 20 & $29 \%$ & 105 & probable transaldolase [Clavicepspurpurea20.1] & \\
\hline \multirow[t]{3}{*}{321} & gi|240280489 & 33573 & 4.83 & 23 & $51 \%$ & 246 & stress protein DDR48 [Ajellomyces capsulatus H143] & \multirow[t]{3}{*}{$\begin{array}{l}\text { [PRK12678] transcription termination factor } \\
\text { Rho; Provisional; E=3.38e-04 }\end{array}$} \\
\hline & gi|154277766 & 32925 & 4.57 & 18 & $46 \%$ & 237 & hypothetical protein HCAG_05184 [Ajellomyces capsulatus NAm1] & \\
\hline & gi|13591791 & 31617 & 4.95 & 17 & $40 \%$ & 229 & mold-specific protein MS95 [Ajellomyces capsulatus] & \\
\hline \multirow[t]{3}{*}{341} & gi|302892809 & 34444 & 6.14 & 18 & $33 \%$ & 151 & predicted protein [Nectria haematococca mpVI 77-13-4] & \multirow{3}{*}{$\begin{array}{l}\text { [cd01337] glyoxysomal and mitochondrial } \\
\text { malate dehydrogenases; } E=0 \mathrm{e}+00 \\
\text { [PLN00106] malate dehydrogenase; } \\
\mathrm{E}=1.30 \mathrm{e}-143\end{array}$} \\
\hline & gi|322695422 & 34218 & 6.46 & 17 & $29 \%$ & 151 & malate dehydrogenase precursor [Metarhizium acridum CQMa 102] & \\
\hline & gi|531862512 & 43794 & 9.21 & 20 & $30 \%$ & 151 & malate dehydrogenase [Ophiocordyceps sinensis CO18] & \\
\hline 364 & gi|531866468 & 36308 & & & & 68 & $\begin{array}{l}\text { outer mitochondrial membrane protein porin [Ophiocordyceps sinensis } \\
\text { CO18] }\end{array}$ & $\begin{array}{l}\text { [cd07306] voltage-dependent anion channel } \\
\text { of the outer mitochondrial membrane; } \\
E=1.10 \mathrm{e}-86 \\
\text { [pfam01459] eukaryotic porin; } \mathrm{E}=1.14 \mathrm{e}-80\end{array}$ \\
\hline \multirow[t]{3}{*}{451} & gi|70984978 & 16922 & 7.77 & 12 & $60 \%$ & 265 & nucleoside diphosphate kinase [Aspergillus fumigatus Af293] & \multirow{3}{*}{$\begin{array}{l}\text { [cd04413] nucleoside diphosphate kinase } \\
\text { group I (NDPk_I)-like; } E=5.04 \mathrm{e}-91 \\
\text { [pfam00334] nucleoside diphosphate kinase; } \\
\mathrm{E}=5.36 \mathrm{e}-88\end{array}$} \\
\hline & gi|471560787 & 16736 & 7.77 & 11 & $41 \%$ & 265 & putative nucleoside diphosphate kinase protein [Eutypa lata UCREL1] & \\
\hline & gi|30315965 & 16898 & 7.82 & 11 & $56 \%$ & 263 & $\begin{array}{l}\text { RecName: Full=Nucleoside diphosphate kinase; Short=NDP kinase; } \\
\text { AltName: Full=AnNDK; Short=NDK }\end{array}$ & \\
\hline 472 & gi|340519078 & 12201 & 4.72 & 5 & $23 \%$ & 103 & predicted protein [TrichodermareeseiQM6a] & $\begin{array}{l}\text { [DUF3759] protein of unknown function; } \\
E=1.93 e-35\end{array}$ \\
\hline
\end{tabular}

Table 3. Summary of Mascot and BLAST search results after $120 \mathrm{~h}$ of the Paecilomyces marquandii culture containing alachlor (50 mg L-1). Mascot algorithm matching - protein scores greater than 73 are significant $(p<0.05)$. Delta-BLAST algorithm - the lower the E-value (closer to zero), the more significant is the match.

\begin{tabular}{|c|c|c|c|c|c|c|c|c|}
\hline \multirow{2}{*}{$\begin{array}{l}\text { Spot } \\
\text { ID. }\end{array}$} & \multicolumn{7}{|c|}{ Mascot search results } & \multirow[t]{2}{*}{ DELTA-BLAST Results } \\
\hline & $\begin{array}{l}\text { Best Protein } \\
\text { Accession }\end{array}$ & $\begin{array}{l}\text { Mass } \\
{[\mathrm{Da}]}\end{array}$ & $\begin{array}{l}\text { Calc. } \\
\text { pl }\end{array}$ & $\begin{array}{l}\text { Peptides } \\
\text { Matched }\end{array}$ & $\begin{array}{l}\text { Seq. } \\
\text { Cov. }\end{array}$ & Score & Best Protein Description & \\
\hline \multirow[t]{3}{*}{160} & gi|531865828 & 72449 & 5.7 & 32 & $32 \%$ & 410 & heat shock $70 \mathrm{kDa}$ protein [Ophiocordyceps sinensis CO18] & \multirow{3}{*}{$\begin{array}{l}\text { [cd11733] nucleotide-binding domain of } \\
\text { human HSPA9, Escherichia coli DnaK, and } \\
\text { similar proteins; } E=0 \mathrm{e}+00 \\
\text { [PRK00290] molecular chaperone DnaK; } \\
\text { Provisional; } E=0 \mathrm{e}+00\end{array}$} \\
\hline & gi|322701734 & 73112 & 5.68 & 40 & $41 \%$ & 368 & heat shock $70 \mathrm{kDa}$ protein precursor [Metarhizium acridum CQMa 102] & \\
\hline & gi|322706829 & 73386 & 5.68 & 37 & $40 \%$ & 367 & heat shock $70 \mathrm{kDa}$ protein [Metarhizium anisopliae ARSEF 23] & \\
\hline \multirow[t]{3}{*}{189} & gi|322700211 & 62929 & 5.38 & 33 & $38 \%$ & 155 & $\begin{array}{l}\text { phosphoglycerate mutase, 2,3-bisphosphoglycerate-independent } \\
\text { [Metarhizium acridum CQMa 102] }\end{array}$ & \multirow{3}{*}{$\begin{array}{l}\text { [PRK05434]phosphoglyceromutase; } \\
\text { Provisional; E=0e+00 } \\
\text { [Superfamily] cl17463, BPG-independent } \\
\text { PGAM N-terminus (iPGM_N) }\end{array}$} \\
\hline & gi|322708166 & 63375 & 5.49 & 33 & $39 \%$ & 155 & $\begin{array}{l}\text { 2,3-bisphosphoglycerate-independent phosphoglycerate mutase (iPGM) } \\
\text { [Metarhizium anisopliae ARSEF 23] }\end{array}$ & \\
\hline & gi|346326764 & 58747 & 5.25 & 26 & $27 \%$ & 125 & $\begin{array}{l}\text { phosphoglycerate mutase, 2,3-bisphosphoglycerate-independent } \\
\text { [Cordyceps militaris CM01] }\end{array}$ & \\
\hline \multirow[t]{3}{*}{201} & gi|358399574 & 56475 & 6.26 & 25 & $28 \%$ & 153 & peroxisomal catalase [Trichoderma atroviride IMI 206040] & \multirow{3}{*}{$\begin{array}{l}\text { [cd08157] fungal catalases similar to yeast } \\
\text { catalases } \mathrm{A} \text { and } \mathrm{T} ; \mathrm{E}=\mathrm{E}+00 \\
\text { [COG0753] catalase; } \mathrm{E}=0 \mathrm{e}+00\end{array}$} \\
\hline & gi|6014693 & 57211 & 6.79 & 21 & $29 \%$ & 123 & catalase isozyme $\mathrm{P}$ [Ajellomyces capsulatus] & \\
\hline & gi|24528587 & 56849 & 6.5 & 14 & $21 \%$ & 123 & catalase [Paracoccidioides brasiliensis] & \\
\hline \multirow[t]{3}{*}{223} & gi|531866883 & 55138 & 5.33 & 33 & $57 \%$ & 146 & ATP synthase beta chain [Ophiocordyceps sinensis CO18] & \multirow{3}{*}{$\begin{array}{l}\text { [cd01133], F1 ATP synthase beta subunit, } \\
\text { nucleotide-binding domain; } E=0 \mathrm{e}+00 \\
\text { [Cdd:pfam00306] ATP synthase alpha/beta } \\
\text { chain, } C \text { terminal domain; } E=1.32 \mathrm{e}-31 \\
\text { [Cdd:pfam02874] ATP synthase alpha/beta } \\
\text { family, beta-barrel domain; } E=3.60 \mathrm{e}-19 \\
\text { [PRK09280] F0-F1 ATP synthase subunit } \\
\text { beta; Validated; } E=0 \mathrm{e}+00\end{array}$} \\
\hline & gi|399171671 & 55040 & 5.48 & 23 & $41 \%$ & 129 & H+-transporting ATP synthase beta chain [Claviceps purpurea 20.1] & \\
\hline & gi|440638891 & 55382 & 5.46 & 28 & $41 \%$ & 117 & $\begin{array}{l}\text { ATP synthase subunit beta, mitochondrial [Pseudogymnoascus } \\
\text { destructans 20631-21] }\end{array}$ & \\
\hline \multirow[t]{3}{*}{$\begin{array}{l}238 / \\
242\end{array}$} & gi|399170765 & 47165 & 5.39 & 15 & $35 \%$ & 288 & $\begin{array}{l}\text { probable enolase (2-phosphoglycerate dehydratase) [Claviceps purpurea } \\
20.1]\end{array}$ & \multirow[t]{3}{*}{$\begin{array}{l}\text { [cd03313] enolase; } \mathrm{E}=\mathrm{Oe}+00 \\
{[\mathrm{PLN00191]} \text { enolase; } \mathrm{E}=0 \mathrm{e}+00}\end{array}$} \\
\hline & gi|477534317 & 47183 & 5.23 & 12 & $30 \%$ & 264 & enolase [Colletotrichum orbiculare MAFF 240422] & \\
\hline & gi|212537563 & 47395 & 5.39 & 13 & $30 \%$ & 171 & enolase/allergen Asp F 22 [Talaromyces marneffei ATCC 18224] & \\
\hline 256 & gi|322696440 & 52422 & 8.43 & 29 & $29 \%$ & 198 & Phosphoglycerate kinase [Metarhizium acridum CQMa 102] & [cd00318] phosphoglycerate kinase (PGK); \\
\hline
\end{tabular}




\begin{tabular}{|c|c|c|c|c|c|c|c|c|}
\hline & gi|322704254 & 44347 & 6.69 & 27 & $36 \%$ & 198 & Phosphoglycerate kinase [Metarhizium anisopliae ARSEF 23] & \multirow{2}{*}{$\begin{array}{l}E=0 e+00 \\
{[\text { Superfamily] cl00198, phosphoglycerate }} \\
\text { kinase (PGK) }\end{array}$} \\
\hline & gi|302886659 & 44613 & 5.43 & 21 & $38 \%$ & 129 & predicted protein [Nectria haematococca mpVI 77-13-4] & \\
\hline \multirow[t]{2}{*}{268} & gi|322702591 & 39769 & 5.53 & 20 & $34 \%$ & 109 & cyanide hydratase [Metarhizium anisopliae ARSEF 23] & \multirow{2}{*}{$\begin{array}{l}\text { [cd07564] nitrilases, cyanide hydratase } \\
(\mathrm{CH}) \mathrm{s} \text {, and similar proteins (class } 1 \\
\text { nitrilases); } \mathrm{E}=2.75 \mathrm{e}-119\end{array}$} \\
\hline & gi|88766405 & 39768 & 5.63 & 20 & $34 \%$ & 109 & cyanide hydratase [Metarhizium anisopliae] & \\
\hline 275 & gi|346322842 & 42559 & & & & 68 & vacuolar protease A precursor [Cordyceps militaris $\mathrm{CM} 01$ ] & $\begin{array}{l}\text { [cd05471] pepsin-like aspartic proteases; } \\
E=3.95 \mathrm{e}-97 \\
\text { [pfam00026] eukaryotic aspartyl protease; } \\
E=1.54 \mathrm{e}-119\end{array}$ \\
\hline \multirow[t]{3}{*}{285} & gi|225559211 & 36835 & 8.26 & 16 & $28 \%$ & 80 & $\begin{array}{l}\text { NADP-dependent glycerol dehydrogenase [Ajellomyces capsulatus } \\
\text { G186AR] }\end{array}$ & \multirow[t]{3}{*}{ [cd06660] aldo-keto reductases; $E=7.51 \mathrm{e}-78$} \\
\hline & gi|261204493 & 37322 & 6.28 & 15 & $30 \%$ & 80 & aldehyde reductase I [Ajellomyces dermatitidis SLH14081] & \\
\hline & gi|239614213 & 37350 & 6.43 & 15 & $29 \%$ & 80 & aldehyde reductase I [Ajellomyces dermatitidis ER-3] & \\
\hline \multirow[t]{3}{*}{286} & gi|429862698 & 36234 & 6.25 & 33 & $55 \%$ & 366 & $\begin{array}{l}\text { glyceraldehyde-3-phosphate dehydrogenase [Colletotrichum } \\
\text { gloeosporioides Nara gc5] }\end{array}$ & \multirow{3}{*}{$\begin{array}{l}\text { [pfam02800] glyceraldehyde 3-phosphate } \\
\text { dehydrogenase, C-terminal domain; } \\
E=7.93 e-100 \\
\text { [pfam00044] glyceraldehyde 3-phosphate } \\
\text { dehydrogenase, NAD binding domain; } \\
E=9.57 \mathrm{e}-80 \\
\text { [COG0057] glyceraldehyde-3-phosphate } \\
\text { dehydrogenase/erythrose-4-phosphate } \\
\text { dehydrogenase; } \mathrm{E}=0 \mathrm{e}+00\end{array}$} \\
\hline & gi|530477121 & 36248 & 6.25 & 31 & $55 \%$ & 335 & $\begin{array}{l}\text { glyceraldehyde-3-phosphate dehydrogenase [Colletotrichum } \\
\text { gloeosporioides Cg-14] }\end{array}$ & \\
\hline & gi|477536372 & 36232 & 6.24 & 30 & $51 \%$ & 333 & $\begin{array}{l}\text { glyceraldehyde-3-phosphate dehydrogenase [Colletotrichum orbiculare } \\
\text { MAFF 240422] }\end{array}$ & \\
\hline \multirow[t]{3}{*}{295} & gi|302884358 & 39125 & 5.24 & 13 & $27 \%$ & 139 & fructose-bisphosphate aldolase [Nectria haematococca mpVI 77-13-4] & \multirow{3}{*}{$\begin{array}{l}\text { [PRK09197] fructose-bisphosphate aldolase; } \\
\text { Provisional; } \mathrm{E}=0 \mathrm{e}+00 \\
\text { [Superfamily] cl17181, fructose/tagarose- } \\
\text { bisphosphate aldolase class II }\end{array}$} \\
\hline & gi|342871910 & 37275 & 5.24 & 10 & $21 \%$ & $\begin{array}{l}127 \\
127\end{array}$ & hypothetical protein FOXB_15150 [Fusarium oxysporum Fo5176] & \\
\hline & gi|475673861 & 39633 & 5.44 & 10 & $20 \%$ & & $\begin{array}{l}\text { Fructose-bisphosphate aldolase [Fusarium oxysporum f. sp. cubense race } \\
\text { 4] }\end{array}$ & \\
\hline \multirow[t]{3}{*}{307} & gi|322697295 & 35337 & 6.49 & 38 & $51 \%$ & 207 & transaldolase [Metarhizium acridum CQMa 102] & \multirow{3}{*}{$\begin{array}{l}\text { [cd00957] transaldolases including both TalA } \\
\text { and TalB; } E=2.63 \mathrm{e}-176 \\
\text { [PTZ00411] transaldolase-like protein; } \\
\text { Provisional; } E=5.88 \mathrm{e}-152\end{array}$} \\
\hline & gi|322712191 & 34600 & 6.86 & 35 & $44 \%$ & 195 & transaldolase [Metarhizium anisopliae ARSEF 23] & \\
\hline & gi|531856223 & 35087 & 6.86 & 34 & $49 \%$ & 194 & Transaldolase [Ophiocordyceps sinensis CO18] & \\
\hline \multirow[t]{3}{*}{311} & gi|322697295 & 35337 & 6.49 & 30 & $39 \%$ & 76 & transaldolase [Metarhizium acridum CQMa 102] & \multirow{3}{*}{$\begin{array}{l}\text { [cd00957] transaldolases including both TalA } \\
\text { and TalB; } E=2.63 \mathrm{e}-176 \\
\text { [PTZ00411] transaldolase-like protein; } \\
\text { Provisional; } E=5.88 \mathrm{e}-152\end{array}$} \\
\hline & gi|322712191 & 34600 & 6.86 & 28 & $41 \%$ & 76 & transaldolase [Metarhizium anisopliae ARSEF 23] & \\
\hline & gi|399165577 & 35653 & 5.64 & 23 & $29 \%$ & 76 & probable transaldolase [Claviceps purpurea 20.1] & \\
\hline \multirow[t]{3}{*}{314} & gi 67539148 & 30223 & 4.85 & 16 & $28 \%$ & 161 & hypothetical protein AN5744.2 [Aspergillus nidulans FGSC A4] & \multirow{3}{*}{$\begin{array}{l}\text { [cd11309] fungal 14-3-3 protein domain; } \\
E=2.80 \mathrm{e}-138 \\
\text { [Superfamily] cl02098, 14-3-3 domain }\end{array}$} \\
\hline & gi|46108718 & 27506 & 4.94 & 14 & $22 \%$ & 161 & hypothetical protein FG01241.1 [Fusarium graminearum $\mathrm{PH}-1$ ] & \\
\hline & gi|70991439 & 30085 & 4.74 & 16 & $35 \%$ & 161 & 14-3-3 family protein [Aspergillus fumigatus Af293] & \\
\hline \multirow[t]{3}{*}{$323 / 4$} & gi|302654183 & 20680 & 4.83 & 15 & $20 \%$ & 202 & conserved hypothetical protein [Trichophyton verrucosum HKI 0517] & \multirow{3}{*}{$\begin{array}{l}\text { [PRK12678] transcription termination factor } \\
\text { Rho; Provisional; } E=0.01 \\
\text { [PRK08581] N-acetylmuramoyl-L-alanine } \\
\text { amidase; Validated; } E=0.03\end{array}$} \\
\hline & gi|530473648 & 32195 & 4.45 & 20 & $47 \%$ & 187 & hypothetical protein CGLO_06169 [Colletotrichum gloeosporioides Cg-14] & \\
\hline & gi|261196113 & 40526 & 6.85 & 32 & $46 \%$ & 186 & mold-specific protein [Ajellomyces dermatitidis SLH14081] & \\
\hline 384 & gi|401888325 & 27630 & 7.64 & 15 & $40 \%$ & 75 & L-xylulose reductase [Trichosporon asahii var. asahii CBS 2479] & $\begin{array}{l}\text { [cd05352] mannitol dehydrogenase (MDH)- } \\
\text { like, classical (c) SDRs; } E=1.03 e-119 \\
\text { [PRK05557] 3-ketoacyl-(acyl-carrier-protein) } \\
\text { reductase; Validated; } E=1.81 \mathrm{e}-52\end{array}$ \\
\hline \multirow[t]{3}{*}{396} & gi|346327419 & 26911 & 6.02 & 14 & $32 \%$ & 139 & triosephosphate isomerase [Cordyceps militaris CM01] & \multirow{3}{*}{$\begin{array}{l}\text { [cd00311] triosephosphate isomerase (TIM); } \\
E=8.40 \mathrm{e}-111\end{array}$} \\
\hline & gi|315042127 & 27047 & 5.59 & 12 & $30 \%$ & 110 & triosephosphate isomerase [Arthroderma gypseum CBS 118893] & \\
\hline & gi|302672679 & 26429 & 6.1 & 6 & $10 \%$ & 104 & $\begin{array}{l}\text { hypothetical protein SCHCODRAFT_71461 [Schizophyllum commune H4- } \\
\text { 8] }\end{array}$ & \\
\hline 423 & gi|46124419 & 23107 & & & & 72 & RS7_NEUCR 40S ribosomal protein S7 [Fusarium graminearum PH-1] & $\begin{array}{l}\text { [pfam01251] ribosomal protein S7e; } \\
\mathrm{E}=5.11 \mathrm{e}-101\end{array}$ \\
\hline 426 & gi|322707797 & 24900 & & & & 60 & manganese superoxide dismutase [Metarhizium anisopliae ARSEF 23] & $\begin{array}{l}\text { [pfam02777] iron/manganese superoxide } \\
\text { dismutases, C-terminal domain; } E=1.25 \mathrm{e}-50 \\
\text { (super family) cl02809; } \mathrm{E}=1.92 \mathrm{e}-33 \\
\text { [COG0605] superoxide dismutase; } \mathrm{E}=7.09 \mathrm{e}- \\
90\end{array}$ \\
\hline \multirow[t]{3}{*}{460} & gi|340518820 & 14822 & 10.12 & 16 & $48 \%$ & 86 & histone H2B [Trichoderma reesei QM6a] & \multirow{3}{*}{$\begin{array}{l}\text { [smart00427] histone } \mathrm{H} 2 \mathrm{~B} ; \mathrm{E}=4.30 \mathrm{e}-49 \\
\text { [Superfamily] cl00074, histone } \mathrm{H} 4\end{array}$} \\
\hline & gi|358385634 & 14836 & 10.12 & 16 & $48 \%$ & 86 & hypothetical protein TRIVIDRAFT_92198 [Trichoderma virens Gv29-8] & \\
\hline & gi|51701481 & 14789 & 10.16 & 14 & $42 \%$ & 86 & RecName: Full=Histone H2B & \\
\hline 496 & gi|340519078 & 12201 & 4.72 & 7 & $23 \%$ & 82 & predicted protein [Trichoderma reesei QM6a] & $\begin{array}{l}\text { [DUF3759] protein of unknown function; } \\
E=1.93 \mathrm{e}-35\end{array}$ \\
\hline
\end{tabular}

cultures, significantly increased expression of this group of proteins, resulting in 11 enzymes identified in comparison to control samples where only 4 enzymes from this group were found. This result is in agreement with the glucose metabolism data wherein the alachlorcontaining cultures exhibit slower growth and glucose uptake, leading to the differences in the metabolic pathways courses. The upregulation of the energy-related and sugars metabolism proteins during xenobiotics biodegradation seems to be a common effect of its presence in the culture $[11,30]$. The upregulation of reactive oxygen species (ROS) enzymes represented by the manganese superoxide dismutase and catalase was observed in alachlor- containing cultures. The production of ascorbate as well as results from our proteomic studies support the fact that during alachlor biodegradation, ROS are generated and both classes of compounds may act as a self-defense mechanism during xenobiotic removal. Similar upregulation of ROS enzymes was observed in cultures of $M$. robertsii exposed to 4- $n$-NP [11]. On the other hand, the ROS enzymes' oxidoreductase activity towards alachlor itself cannot be excluded as the enzymes expression may take place under other physiological and non-physiological conditions [31]. In addition, the typical stress response protein - heat shock $70 \mathrm{kDa}$ protein, was upregulated only in alachlor-containing cultures as in the cultures of 
M. plumbeus exposed to pentachlorophenol (PCP) [12]. An interesting result was obtained from alachlor-containing culture spot 268 , identified as cyanide hydratase - a nitrilase (class 1 nitrilase or nitrile aminohydrolase), which is capable of hydrolyze nitriles (RCN) to ammonia and the corresponding carboxylic acid. Most nitrilases prefer aromatic nitriles, some prefer aryl acetonitriles and other aliphatic nitriles. The mechanism of alachlor biodegradation was explained in our previous work [16], illustrating that the pathway includes changes in the aliphatic substituent of alachlor, leading to the dechlorination and the formation of different oxidized forms (ex. carboxylic acids, ketones or alcohols) of both chains situated next to the $\mathrm{C}-\mathrm{N}$ bond of 1-(2,6-diethylphenyl)methanamine substituent. Given the overexpression of this enzyme in cultures upon xenobiotic addition, it is likely that it is a key protein involved in the $P$. marquandii-mediated biodegradation process of alachlor.

\section{Conclusion}

The living cell is a huge biochemical manufacturer - our research focused on a specific process, but more detailed information on multilevel metabolic adaptations may provide a better understanding of any environmentally relevant organism, allowing us to enhance or modify a given process for specific purposes. To our knowledge, this is the first study combining proteomics and primary metabolomics to assess alachlor biodegradation by a fungal strain.

Our data indicate that the addition of alachlor reduced culture growth and glucose consumption rate. However, the carbon source metabolism increased (glycolysis and TCA cycle) during the initial stage of growth, and a shift towards the formation of supplementary materials (UDP-glucose/galactose) and ascorbate (powerful ROS scavenger) was observed. The proteomics of the process tested revealed that, in the presence of a strong xenobiotic, sugars, as well as energy, metabolism and ROS enzymes are upregulated. Additionally, the unique overexpression of cyanide hydratase in alachlor-containing cultures, which hydrolyze nitriles to ammonia and the corresponding carboxylic acid, may indicate that this enzyme is the most important in the process examined.

The characterization of alachlor removal by $P$. marquandii, including xenobiotic pathway research [16] and trend analysis, basic physiological measurements, combined with primary metabolite profiling and proteomics, resulted in deeper insight into a microorganism's approach towards xenobiotic biodegradation on various levels of cell structure and functionality.

\section{Acknowledgments}

This study was supported by the grant of the National Science Centre, Poland (Project No. UMO-2011/01/B/NZ9/02898).

\section{References}

[1] P. Böger, B. Matthes, J. Schmalfuß, Towards the primary target of chloroacetamides - new findings pave the way, Pest. Man. Sci. 56 (2000) 497508 .

[2] L.D. Sette, L.A. Mendonca Alves da Costa, A.J. Marsaioli, G.P. Manfio, Biodegradation of alachlor by streptomycetes, Appl. Microbiol. Biotechnol. 64 (2004) $712-717$

[3] L. Fava, P. Bottoni, A. Crobe, E. Funari, Leaching properties of some degradation products of attoni, A. Crobe, E. Funari, Leaching properties of some degrada

[4] D.M. Tessier, J.M. Clark, Quantitative assessment of the mutagenic potential of D.M. Tessier, J.M. Clark, Quantitative assessment of the mutagenic potential of
environmental degradative products of alachlor, J. Agric. Food Chem. 43 (1995) environmental degradative products of alachlor, J. Agric. Food Chem. 43 (1995)
$2504-2512$.

[5] C.Z. Chen, C.T. Yan, P.V. Kumar, J.W. Huang, J.F. Jen, Determination of alachlorand its metabolite 2,6-diethylaniline in microbial culture medium using online microdialysis enriched sampling coupled to high performance liquid chromatography,J. Agric. Food Chem. 59 (2011) 8078-8085.

[6] W. Charles, D. Knappa, W. Grahama, G. Berardescoa, F. de Noyelles Jr, B.J. Cutakd, C.K. Larive, Nutrient level, microbial activity, and alachlor transformation inaerobic aquatic systems. Water Res. 37(2003) 4761-4769.

[7] A.E.M. Chirnside, W.F. Ritter, M. Radosevich, Biodegradation of aged residuesof atrazine and alachlor in a mix-load site soil. Soil Biol.Biochem. 41 (2009) 24842492.

[8] Munoz, W.C. Koskinen, L. Cox, M.J. Sadowsky, Biodegradation and mineralization of metolachlor and alachlor by Candida xestobii, J. Agric. Food Chem. 59 (2011) 619-627.

[9] J.-S. Seo, Y.-S. Keum, Q.X. Li, Metabolomic and proteomic insights into carbaryl catabolism by Burkholderia sp. $\mathrm{C} 3$ and degradation of ten $\mathrm{N}$-methylcarbamates, Biodegradation 24 (2013) 795-811.

[10] Y.S. Keum, J.S. Seo, Q.X. Li, J.H. Kim, Comparative metabolomic analysis of Sinorhizobium sp. C4 during the degradation of phenanthrene, Appl. Microbiol. Sinorhizobium sp. C4 during the

[11] R. Szewczyk, A. Soboń, S. Różalska, K. Dzitko, D. Waidelich, J. Długoński, Intracellular proteome expression during $4-n$-nonylphenol biodegradation by the filamentous fungus Metarhizium robertsii, Int. Biodeterior. Biodegrad. 93 (2014) 44-53.

[12] M.B. Carvalho, I. Martins, J. Medeiros, S. Tavares, S. Planchon, J. Renaut, O. Núñez, H. Gallart-Ayala, M.T. Galceran, A. Hursthouse, C. Silva Pereira, The response of Mucor plumbeus to pentachlorophenol: a toxicoproteomics study, J. Proteomics 78 (2013) 159-171.
[13] F. Matsuzaki, M. Shimizu, H. Wariishi, 2008. Proteomic and metabolomic analyses of the White-Rot fungus Phanerochaete chrysosporium exposed to exogenous benzoic acid, J. Proteome Res. 7 (2008) 2342-2350.

[14] X. Zhang, X. Liu, W. Chai, J. Wei, Q. Wang, B. Li, H. Li, The use of proteomic analysis for exploring the phytoremediation mechanism of Scirpus triqueter to pyrene, J. Hazard. Mater. 260 (2013) 1001-1007.

[15] C. Agrawal, S. Sen, S. Singh, S. Rai, P.K. Singh, V.K. Singh, L.C. Rai, Comparative proteomics reveals association of early accumulated proteins in conferring butachlor tolerance in three N2-fixing Anabaena sp., J. Proteomics 96 (2014) 271-290.

[16] M. Słaba, R. Szewczyk, M.A. Piątek, J. Długoński, Alachlor oxidation by the filamentous fungus Paecilomyces marquandii, J. Hazard. Mater. 261 (2013) 443450

[17] M. Słaba, J. Długoński, Selective recovery of $\mathrm{Zn}^{2+}$ from waste slag from a metalprocessing plant by microscopic fungus Verticillium marquandii, Biotechnol. Lett. 22 (2000) 1699-1704.

[18] R. Wei, G. Li, A.B. Seymour, High-throughput and multiplexed LC/MS/MRM R. Wei, G. Li, A.B. Seymour, High-throughput and multiplexed LC/Ms
method for targeted metabolomics, Anal. Chem. 82 (2010) 5527-5533.

[19] S. Różalska, R. Szewczyk, J. Długoński, Biodegradation of 4-n-nonylphenol by the non-ligninolytic filamentous fungus Gliocephalotrichum simplex: a proposalof a metabolic pathway, J. Hazard. Mater. 180 (2010) 323-331.

[20] D.N. Perkins, D.J. Pappin, D.M. Creasy, J.S. Cottrell, Probability-based protein identification by searching sequence databases using mass spectrometry data Electrophoresis 20 (1999) 3551-3567.

[21] S.F. Altschul, W. Gish, W. Miller, E.W. Myers, D.J. Lipman, Basic local alignment search tool, J. Mol. Biol. 215 (1990) 403-410.

[22] Basic Local Alignment Search Tool, The National Center for Biotechnology Information, 2014 online at: http://blast.stva.ncbi.nlm.nih.gov/Blast.cgi?PROGRAM=blastp\&PAGE_TYPE=BlastSearch\&LI NK LOC=blasthome

[23] D. Miura, H. Tanaka, H. Wariishi, Metabolomic differential display analysis of the white-rot basidiomycete Phanerochaete chrysosporium grown under air and $100 \%$ oxygen, FEMS Microbiol. Let. 234 (2004) 111-116.

[24] M. Ringnér, What is principal component analysis?, Nat. Biotechnol. 26 (2008) M. Ringn 304 .

[25] S.S. Doyle, Fungal proteomics: from identification to function. FEMS Microbiol. Lett. 321 (2011) 1-9. [26] B. Bregar, S. Mandelc, F. Celar, B. Javornik, Proteome analysis of the plant
pathogenic fungus Monilinia laxa showing host specificity, Food Technol. pathogenic fungus Monilinia
Biotechnol. 50 (2012) 326-333.

[27] D. Salvachúa, A.T. Martínez, M. Tien, M.F. López-Lucendo, F. García, V. de Los Ríos, M.J. Martínez, A. Prieto, Differential proteomic analysis of the secretome of Irpex lacteus and other white-rot fungi during wheat straw pretreatment Biotechnol. Biofuels 6 (2013) 115.

[28] K. Kroll, V. Pähtz, O. Kniemeyer, Elucidating the fungal stress response by proteomics, J. Proteomics 97 (2014) 151-163.

[29] J.M.P.F. Ferreira de Oliveira, L.H. de Graaff, Proteomics of industrial fungi: trends and insights for biotechnology, Appl. Microbiol. Biotechnol. 89 (2011) 225-237.

[30] X. Yang, J.-Y. Sun, J.-L. Guob, X.-Y. Weng, Identification and proteomic analysis of a novel gossypol-degrading fungal strain, J. Sci. Food Agric. 92 (2012) 943 951.

[31] J. Fujii, Y. Ikeda, Advances in our understanding of peroxiredoxin, a multifunctional, mammalian redox protein, Redox Rep. 7 (2002) 123-130. 


\section{Mechanism study of alachlor biodegradation by Paecilomyces marquandii with proteomic and metabolomic methods.}

Rafał Szewczyk, Adrian Soboń, Mirosława Słaba, Jerzy Długoński

"Department of Biotechnology and Industrial Microbiology, Institute of Microbiology, Biotechnology and Immunology, Faculty of Biology and Environmental Protection, University of Łódź, Banacha 12/16, 90-237 Łódź, Poland, tel. +4842 6354465 , Fax. +4842 6655818 , jdlugo@biol.uni.lodz.pl

\section{SUPPORTING MATERIAL}

\section{Contents}

Table S-1 - page 1

Table S-2 - page 2

Table S-3 - page 4

Table S-1. Multiple reaction monitoring (MRM) MS/MS scan mode - compound dependant parameters applied in the screening method.

\begin{tabular}{|c|c|c|c|c|c|c|c|}
\hline Q1 & Q3 & $\begin{array}{c}\text { dwell } \\
\text { time (ms) }\end{array}$ & id & DP & EP & CE & CXP \\
\hline 185 & 97 & 5 & 3-Phosphoglycerate & -50 & -10 & -22 & -10 \\
\hline 101 & 57 & 5 & Acetoacetate & -50 & -10 & -15 & -10 \\
\hline 403.6 & 79 & 5 & Acetyl-CoA & -50 & -10 & -60 & -10 \\
\hline 173 & 129 & 5 & Aconitate & -50 & -10 & -8 & -10 \\
\hline 426 & 79 & 5 & ADP & -100 & -10 & -60 & -10 \\
\hline 145.1 & 101 & 5 & a-Keto-glutarate/Adipate & -50 & -10 & -21 & -10 \\
\hline 346.1 & 79 & 5 & AMP & -70 & -10 & -43 & -10 \\
\hline 175 & 115 & 5 & Ascorbate & -50 & -10 & -17 & -10 \\
\hline 506 & 159 & 5 & ATP & -100 & -10 & -45 & -10 \\
\hline 191 & 111 & 5 & Citrate & -50 & -10 & -13 & -10 \\
\hline 339 & 241 & 5 & F26BP/G16BP & -50 & -10 & -20 & -10 \\
\hline 115 & 71 & 5 & Fumarate/Maleate & -50 & -10 & -15 & -10 \\
\hline 259 & 79 & 5 & G1P/G6P/F1P/F6P & -60 & -10 & -35 & -10 \\
\hline 193 & 113 & 5 & Glucoronate & -60 & -10 & -22 & -10 \\
\hline 89 & 59 & 5 & Glyceraldehyde & -50 & -10 & -10 & -10 \\
\hline 185 & 79.1 & 5 & Glycerate-2-P & -50 & -10 & -30 & -10 \\
\hline 93 & 57 & 5 & Glycerol & 50 & 10 & 12 & 10 \\
\hline 171 & 79 & 5 & Glycerol-3-P & -50 & -10 & -22 & -10 \\
\hline 181.1 & 137.1 & 5 & Homovanillate & -50 & -10 & -12 & -10 \\
\hline 89 & 43 & 5 & Lactate & -50 & -10 & -20 & -10 \\
\hline 133 & 115 & 5 & Malate & -50 & -10 & -20 & -10 \\
\hline 103 & 59 & 5 & Malonate & -50 & -10 & -15 & -10 \\
\hline 425.6 & 79 & 5 & Malonyl-CoA & -50 & -10 & -62 & -10 \\
\hline 117 & 73 & 5 & Methylmalonate/Succinate & -50 & -10 & -12 & -10 \\
\hline 147.1 & 59 & 5 & Mevalonate & -50 & -10 & -19 & -10 \\
\hline 89 & 61 & 5 & Oxalate & -50 & -10 & -18 & -10 \\
\hline 131 & 87 & 5 & Oxaloacetate & -50 & -10 & -9 & -10 \\
\hline 167 & 79 & 5 & PEP & -50 & -10 & -31 & -10 \\
\hline 73 & 55 & 5 & Propionate & -50 & -10 & -20 & -10 \\
\hline 87 & 43 & 5 & Pyruvate & -50 & -10 & -12 & -10 \\
\hline 565.1 & 323 & 5 & $\begin{array}{l}\text { UDP-glucose/UDP- } \\
\text { galactose }\end{array}$ & -60 & -10 & -30 & -10 \\
\hline 579 & 403 & 5 & UDP-glucuronate & -50 & -10 & -28 & -10 \\
\hline
\end{tabular}


Table S-2. Full set of Mascot and BLAST protein id search results after 120h of the P. marquandii control culture. Mascot algorithm matching protein scores greater than 73 are significant $(p<0.05)$. Delta-BLAST algorithm - the lower the E-value (closer to zero), the more significant is the match. Green - identified (high score and/or high sequence coverage), yellow - functionally assigned by delta-BLAST (with low Mascot score), white - unidentified (very low Mascot score).

\begin{tabular}{|c|c|c|c|c|c|c|c|c|}
\hline \multirow{2}{*}{$\begin{array}{l}\text { Spo } \\
\text { t ID. }\end{array}$} & \multicolumn{7}{|c|}{ Mascot search result } & \multirow[t]{2}{*}{ DELTA-BLAST Results } \\
\hline & $\begin{array}{l}\text { Best Protein } \\
\text { Accession }\end{array}$ & $\begin{array}{l}\text { Mass } \\
{[\mathrm{Da}]}\end{array}$ & $\begin{array}{l}\text { Calc. } \\
\mathrm{pl}\end{array}$ & $\begin{array}{l}\text { Peptides } \\
\text { Matched }\end{array}$ & $\begin{array}{l}\text { Seq. } \\
\text { Cov. }\end{array}$ & Score & Best Protein Description & \\
\hline 167 & gi|511008026 & 87992 & & & & 41 & $\begin{array}{l}\text { hypothetical protein HMPREF1544_03925 [Mucor } \\
\text { circinelloides f. circinelloides 1006PhL] }\end{array}$ & No match \\
\hline 174 & gi|471569154 & 94445 & & & & 44 & $\begin{array}{l}\text { putative beta-glucosidase } 1 \text { precursor protein [Eutypa } \\
\text { lata UCREL1] }\end{array}$ & No match \\
\hline $\begin{array}{l}193 / \\
194\end{array}$ & gi|358058207 & 72974 & & & & 29 & $\begin{array}{l}\text { hypothetical protein E5Q_02659 [Mixia osmundae IAM } \\
\text { 14324] }\end{array}$ & No match \\
\hline 196 & gi|23894273 & 1401 & & & & 9 & SSU1 protein [Saccharomyces cerevisiae] & No match \\
\hline 200 & gi|154320359 & 19709 & & & & 40 & predicted protein [Botryotinia fuckeliana B05.10] & No match \\
\hline 208 & gi|396489610 & 108166 & & & & 34 & $\begin{array}{l}\text { hypothetical protein LEMA_P089070.1 [Leptosphaeria } \\
\text { maculans JN3] }\end{array}$ & No match \\
\hline 213 & gi|521582664 & 93600 & & & & 7 & $\begin{array}{l}\text { hypothetical protein PFL1_05814 [Pseudozyma } \\
\text { flocculosa PF-1] }\end{array}$ & No match \\
\hline 227 & gi|521585597 & 126585 & & & & 44 & $\begin{array}{l}\text { hypothetical protein PFL1_03029 [Pseudozyma } \\
\text { flocculosa PF-1] }\end{array}$ & No match \\
\hline 239 & gi|310793840 & 101748 & & & & 25 & $\begin{array}{l}\text { F-box domain-containing protein [Colletotrichum } \\
\text { graminicola M1.001] }\end{array}$ & No match \\
\hline \multirow[t]{3}{*}{$\begin{array}{l}249 / \\
247\end{array}$} & gi|358398002 & 54863 & 5.47 & 31 & $50 \%$ & 194 & \multirow{3}{*}{$\begin{array}{l}\text { ATP synthase beta chain mitochondrial precursor } \\
\text { [Trichoderma atroviride IMI 206040] } \\
\text { ATP synthase beta chain [Beauveria bassiana ARSEF } \\
\text { 2860] } \\
\text { putative atp synthase beta mitochondrial precursor } \\
\text { protein [Eutypa lata UCREL 1] }\end{array}$} & \multirow{3}{*}{$\begin{array}{l}\text { [cd01133] F1- ATP synthase beta subunit, nucleotide-binding } \\
\text { domain; } E=0 e+00 \\
\text { [cl08258] ATP synthase alpha/beta chain, C-terminal domain; } \\
E=2.38 \mathrm{e}-33 \\
\text { [Cl18399] ATP synthase alpha/beta family, beta-barrel domain; } \\
E=5.22 \mathrm{e}-19 \\
\text { [PRK09280] F0-F1 ATP synthase subunit beta; } \\
\text { Validated;E=0e+00 }\end{array}$} \\
\hline & gi|400595077 & 55284 & 5.26 & 29 & $45 \%$ & 171 & & \\
\hline & gi|471567117 & 54831 & 5.46 & 25 & $38 \%$ & 159 & & \\
\hline 250 & gi|325092938 & 6030 & & & & 16 & $\begin{array}{l}\text { conserved hypothetical protein [Ajellomyces capsulatus } \\
\text { H88] }\end{array}$ & No match \\
\hline 252 & gi|85096905 & 104082 & & & & 35 & $\begin{array}{l}\text { hypothetical protein NCU07082 [Neurospora crassa } \\
\text { OR74A] }\end{array}$ & No match \\
\hline 260 & gi|171687114 & 24558 & & & & 13 & hypothetical protein [Podospora anserina S mat+] & No match \\
\hline 267 & gi|530464730 & 1055 & & & & 13 & $\begin{array}{l}\text { hypothetical protein CGLO_13888 [Colletotrichum } \\
\text { gloeosporioides } \mathrm{Cg}-14 \text { ] }\end{array}$ & No match \\
\hline 273 & gi|387594736 & 5913 & & & & 19 & $\begin{array}{l}\text { hypothetical protein NEQG_00530 [Nematocida parisii } \\
\text { ERTm3] }\end{array}$ & No match \\
\hline 274 & gi|336377750 & 5777 & & & & 19 & $\begin{array}{l}\text { hypothetical protein SERLADRAFT_374663 [Serpula } \\
\text { lacrymans var. lacrymans S7.9] }\end{array}$ & No match \\
\hline 281 & & & & & & & no match & No match \\
\hline 287 & gi|154310718 & 3693 & & & & 12 & predicted protein [Botryotinia fuckeliana B05.10] & No match \\
\hline 293 & gi|393237102 & 6062 & & & & 7 & $\begin{array}{l}\text { hypothetical protein AURDEDRAFT 45010, partial } \\
\text { [Auricularia delicata TFB-10046 SS5] }\end{array}$ & No match \\
\hline 304 & gi| 401837510 & 44664 & & & & 33 & $\begin{array}{l}\text { SLU7-like protein [Saccharomyces kudriavzevii IFO } \\
\text { 1802] }\end{array}$ & No match \\
\hline 305 & gi|82828 & 3374 & & & & 37 & $\begin{array}{l}\text { ribosomal protein L15.e - fission yeast } \\
\text { (Schizosaccharomyces pombe) (fragment) }\end{array}$ & No match \\
\hline 314 & $\begin{array}{l}\text { gi|322697295 } \\
\text { gi|322712191 } \\
\text { gi|399165577 }\end{array}$ & $\begin{array}{l}35337 \\
34600 \\
35653\end{array}$ & $\begin{array}{l}6.49 \\
6.86 \\
5.64\end{array}$ & $\begin{array}{l}30 \\
27 \\
20\end{array}$ & $\begin{array}{l}51 \% \\
34 \% \\
29 \%\end{array}$ & $\begin{array}{l}105 \\
105 \\
105\end{array}$ & $\begin{array}{l}\text { Transaldolase [Metarhizium acridum CQMa 102] } \\
\text { transaldolase [Metarhizium anisopliae ARSEF 23] } \\
\text { probable transaldolase [Claviceps purpurea 20.1] }\end{array}$ & $\begin{array}{l}\text { [cd00957] transaldolases including both TalA and TalB; } \\
\text { E=2.63e-176 } \\
\text { [PTZ00411] transaldolase-like protein; Provisional; E=5.88e-152 }\end{array}$ \\
\hline 317 & gi|363750480 & 6967 & & & & 18 & $\begin{array}{l}\text { hypothetical protein Ecym } 3136 \text { [Eremothecium } \\
\text { cymbalariae DBVPG\# } 721 \overline{5} \text { ] }\end{array}$ & No match \\
\hline 319 & gi|74620637 & 172929 & & & & 17 & $\begin{array}{l}\text { RecName: Full=Pentafunctional AROM polypeptide; } \\
\text { Includes: RecName: Full=3-dehydroquinate synthase; } \\
\text { Short=DHQS; Includes: RecName: Full=3- } \\
\text { phosphoshikimate 1-carboxyvinyltransferase; AltName: } \\
\text { Full=5-enolpyruvylshikimate-3-phosphate synthase; } \\
\text { Short=EPS }\end{array}$ & No match \\
\hline \multirow[t]{3}{*}{321} & gi|240280489 & 33573 & 4.83 & 23 & $51 \%$ & 246 & \multirow{3}{*}{$\begin{array}{l}\text { Stress protein DDR48 [Ajellomyces capsulatus H143] } \\
\text { Hypothetical protein HCAG_05184 [Ajellomyces } \\
\text { capsulatus NAm1] } \\
\text { mold-specific protein MS95 [Ajellomyces capsulatus] }\end{array}$} & \multirow[t]{3}{*}{$\begin{array}{l}\text { [PRK12678] transcription termination factor Rho; Provisional; } \\
E=3.38 \mathrm{e}-04\end{array}$} \\
\hline & gi|154277766 & 32925 & 4.57 & 18 & $46 \%$ & 237 & & \\
\hline & gi|13591791 & 31617 & 4.95 & 17 & $40 \%$ & 229 & & \\
\hline 323 & gi|530480609 & 1774 & & & & 12 & $\begin{array}{l}\text { hypothetical protein CGLO_00011 [Colletotrichum } \\
\text { gloeosporioides Cg-14] }\end{array}$ & No match \\
\hline 334 & gi|406607769 & 34985 & & & & 26 & $\begin{array}{l}\text { 37S ribosomal protein } \mathrm{S} 28 \text {, mitochondrial } \\
\text { [Wickerhamomyces ciferrii] }\end{array}$ & No match \\
\hline \multirow[t]{3}{*}{341} & gi|302892809 & 34444 & 6.14 & 18 & $33 \%$ & 151 & \multirow{3}{*}{$\begin{array}{l}\text { predicted protein [Nectria haematococca mpVI 77-13-4] } \\
\text { malate dehydrogenase precursor [Metarhizium acridum } \\
\text { CQMa 102] } \\
\text { malate dehydrogenase [Ophiocordyceps sinensis CO18] }\end{array}$} & \multirow{3}{*}{$\begin{array}{l}\text { [cd01337] glyoxysomal and mitochondrial malate } \\
\text { dehydrogenases; } E=0 e+00 \\
{[P L N 00106] \text { malate dehydrogenase; } E=1.30 \mathrm{e}-143}\end{array}$} \\
\hline & gi|322695422 & 34218 & 6.46 & 17 & $29 \%$ & 151 & & \\
\hline & gi|531862512 & 43794 & 9.21 & 20 & $30 \%$ & 151 & & \\
\hline
\end{tabular}




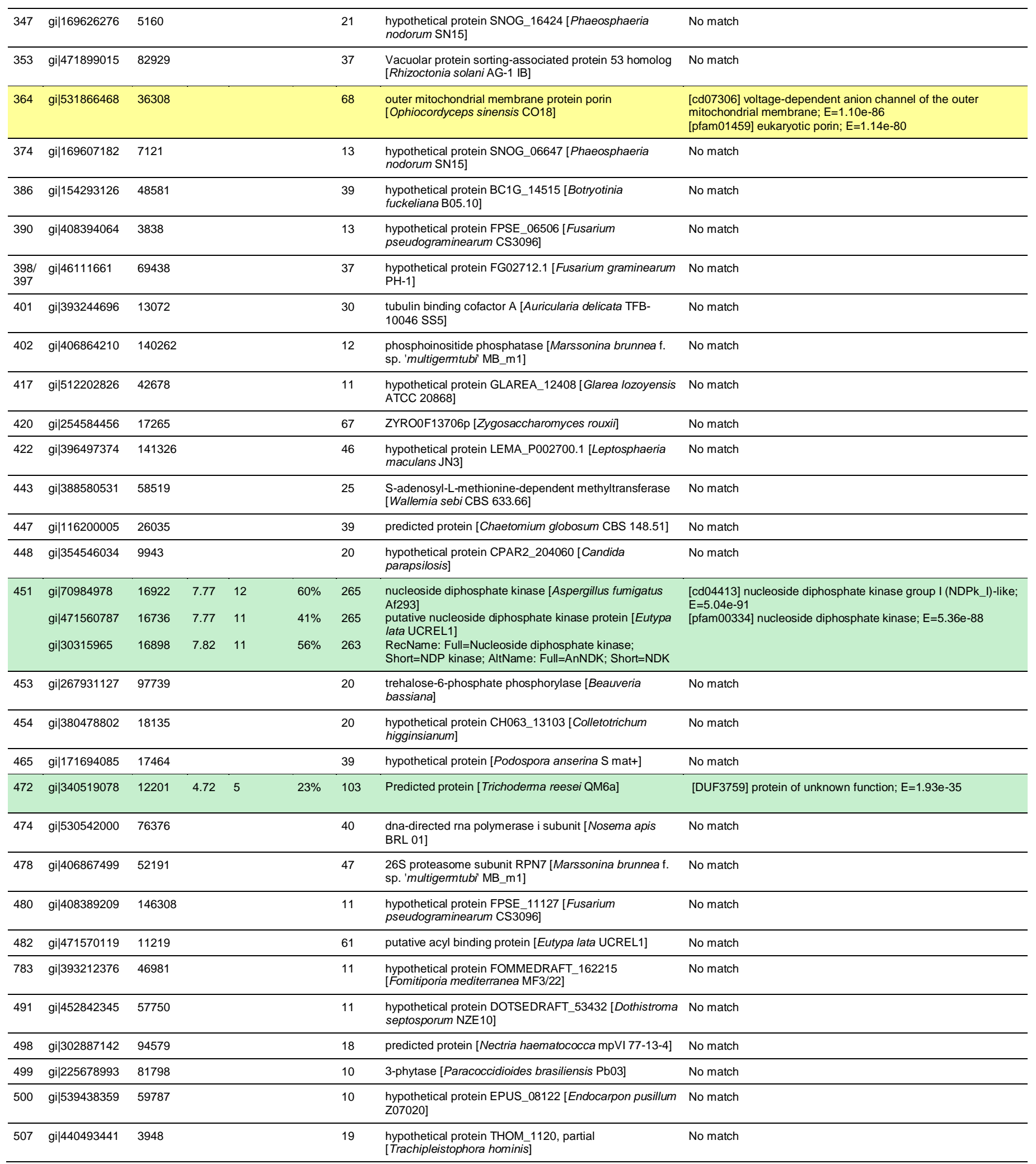

Table S-3. Full set of Mascot and BLAST protein id search results after $120 \mathrm{~h}$ of the $\mathrm{P}$. marquandii culture containing alachlor $\left(50 \mathrm{mg} \mathrm{L}^{-1}\right)$. Mascot algorithm matching - protein scores greater than 73 are significant $(p<0.05)$. Delta-BLAST algorithm - the lower the E-value (closer to zero), the more significant is the match. Green - identified (high score and/or high sequence coverage), yellow - functionally assigned by delta-BLAST (with low Mascot score), white - unidentified (very low Mascot score).

\begin{tabular}{|c|c|c|c|c|c|c|c|c|}
\hline \multirow{2}{*}{$\begin{array}{l}\text { Spo } \\
\text { t } \\
\text { ID. }\end{array}$} & \multicolumn{7}{|c|}{ Mascot search results } & \multirow[t]{2}{*}{ DELTA-BLAST Results } \\
\hline & $\begin{array}{l}\text { Best Protein } \\
\text { Accession }\end{array}$ & $\begin{array}{l}\text { Mass } \\
{[\mathrm{Da}]}\end{array}$ & $\begin{array}{l}\text { Calc. } \\
\mathrm{pl}\end{array}$ & $\begin{array}{l}\text { Peptides } \\
\text { Matched }\end{array}$ & $\begin{array}{l}\text { Seq. } \\
\text { Cov. }\end{array}$ & Score & Best Protein Description & \\
\hline \multirow[t]{2}{*}{160} & gi|531865828 & 72449 & 5.70 & 32 & $32 \%$ & 410 & $\begin{array}{l}\text { heat shock } 70 \mathrm{kDa} \text { protein [Ophiocordyceps sinensis } \\
\text { C018] }\end{array}$ & \multirow{2}{*}{$\begin{array}{l}\text { [cd11733] nucleotide-binding domain of human HSPA9, } \\
\text { Escherichia coli DnaK, and similar proteins; } \mathrm{E}=0 \mathrm{e}+00 \\
\text { [PRK00290] molecular chaperone DnaK; Provisional; } \mathrm{E}=0 \mathrm{e}+00\end{array}$} \\
\hline & gi|322701734 & 73112 & 5.68 & 40 & $41 \%$ & 368 & $\begin{array}{l}\text { heat shock } 70 \mathrm{kDa} \text { protein precursor [Metarhizium } \\
\text { acridum CQMa 102] }\end{array}$ & \\
\hline
\end{tabular}




\begin{tabular}{|c|c|c|c|c|c|c|c|c|}
\hline & gi|322706829 & 73386 & 5.68 & 37 & $40 \%$ & 367 & $\begin{array}{l}\text { heat shock } 70 \mathrm{kDa} \text { protein [Metarhizium anisopliae } \\
\text { ARSEF 23] }\end{array}$ & \\
\hline 163 & gi|387538371 & 70470 & & & & 35 & heat shock protein 70 [B/umeria graminis f. sp. tritici] & No match \\
\hline \multirow[t]{3}{*}{189} & gi|322700211 & 62929 & 5.38 & 33 & $38 \%$ & 155 & \multirow{3}{*}{$\begin{array}{l}\text { phosphoglycerate mutase, 2,3-bisphosphoglycerate- } \\
\text { independent [Metarhizium acridum CQMa 102] } \\
\text { 2,3-bisphosphoglycerate-independent phosphoglycerate } \\
\text { mutase (iPGM) [Metarhizium anisopliae ARSEF 23] } \\
\text { phosphoglycerate mutase, 2,3-bisphosphoglycerate- } \\
\text { independent [Cordyceps militaris CM01] }\end{array}$} & \multirow{3}{*}{$\begin{array}{l}\text { [PRK05434]phosphoglyceromutase; Provisional; E=0e+00 } \\
\text { [Superfamily] cl17463, BPG-independent PGAM N-terminus } \\
\text { (iPGM_N) }\end{array}$} \\
\hline & gi|322708166 & 63375 & 5.49 & 33 & $39 \%$ & 155 & & \\
\hline & gi|346326764 & 58747 & 5.25 & 26 & $27 \%$ & 125 & & \\
\hline 190 & gi|254572409 & 20800 & & & & 42 & hypothetical protein [Komagataella pastoris GS115] & No match \\
\hline \multirow[t]{2}{*}{201} & gi|358399574 & 56475 & 6.26 & 25 & $28 \%$ & 153 & \multirow{2}{*}{$\begin{array}{l}\text { peroxisomal catalase [ Trichoderma atroviride IMI } \\
206040] \\
\text { catalase isozyme P [Ajellomyces capsulatus] } \\
\text { catalase [Paracoccidioides brasiliensis] }\end{array}$} & \multirow{2}{*}{$\begin{array}{l}\text { [cd08157] fungal catalases similar to yeast catalases } \mathrm{A} \text { and } \mathrm{T} \text {; } \\
\mathrm{E}=0 \mathrm{e}+00 \\
\text { [COG0753] catalase; } \mathrm{E}=0 \mathrm{e}+00\end{array}$} \\
\hline & $\begin{array}{l}\text { gi|6014693 } \\
\text { gil24528587 }\end{array}$ & $\begin{array}{l}57211 \\
56849\end{array}$ & 6.79 & 21 & $29 \%$ & 123 & & \\
\hline \multirow[t]{3}{*}{223} & gi|531866883 & 55138 & 5.33 & 33 & $57 \%$ & 146 & \multirow{3}{*}{$\begin{array}{l}\text { ATP synthase beta chain [Ophiocordyceps sinensis } \\
\text { CO18] } \\
\text { H+-transporting ATP synthase beta chain [Claviceps } \\
\text { purpurea 20.1] } \\
\text { ATP synthase subunit beta, mitochondrial } \\
\text { [Pseudogymnoascus destructans 20631-21] }\end{array}$} & \multirow{3}{*}{$\begin{array}{l}\text { [cd01133], F1 ATP synthase beta subunit, nucleotide-binding } \\
\text { domain; } E=0 e+00 \\
\text { [Cdd:pfam00306] ATP synthase alpha/beta chain, } C \text { terminal } \\
\text { domain; } E=1.32 e-31 \\
\text { [Cdd:pfam02874] ATP synthase alpha/beta family, beta-barrel } \\
\text { domain; } E=3.60 \mathrm{e}-19 \\
\text { [PRK09280] F0-F1 ATP synthase subunit beta; Validated; } \\
E=0 e+00\end{array}$} \\
\hline & gi|399171671 & 55040 & 5.48 & 23 & $41 \%$ & 129 & & \\
\hline & gi|440638891 & 55382 & 5.46 & 28 & $41 \%$ & 117 & & \\
\hline \multirow[t]{3}{*}{$\begin{array}{l}238 / \\
242\end{array}$} & gi|399170765 & 47165 & 5.39 & 15 & $35 \%$ & 288 & \multirow{3}{*}{$\begin{array}{l}\text { probable enolase (2-phosphoglycerate dehydratase) } \\
\text { [Claviceps purpurea 20.1] } \\
\text { enolase [Colletotrichum orbiculare MAFF 240422] } \\
\text { enolase/allergen Asp F } 22 \text { [Talaromyces marneffei } \\
\text { ATCC 18224] }\end{array}$} & \multirow[t]{3}{*}{$\begin{array}{l}\text { [cd03313] enolase; } E=0 e+00 \\
{[P L N 00191] \text { enolase; } E=0 e+00}\end{array}$} \\
\hline & gi|477534317 & 47183 & 5.23 & 12 & $30 \%$ & 264 & & \\
\hline & gi|212537563 & 47395 & 5.39 & 13 & $30 \%$ & 171 & & \\
\hline \multirow[t]{3}{*}{256} & gi|322696440 & 52422 & 8.43 & 29 & $29 \%$ & 198 & \multirow{3}{*}{$\begin{array}{l}\text { Phosphoglycerate kinase [Metarhizium acridum CQMa } \\
\text { 102] } \\
\text { Phosphoglycerate kinase [Metarhizium anisopliae } \\
\text { ARSEF 23] } \\
\text { predicted protein [Nectria haematococca mpVI 77-13-4] }\end{array}$} & \multirow[t]{3}{*}{$\begin{array}{l}\text { [cd00318] phosphoglycerate kinase (PGK); } \mathrm{E}=0 \mathrm{e}+00 \\
\text { [Superfamily] cl00198, phosphoglycerate kinase (PGK) }\end{array}$} \\
\hline & gi|322704254 & 44347 & 6.69 & 27 & $36 \%$ & 198 & & \\
\hline & gi|302886659 & 44613 & 5.43 & 21 & $38 \%$ & 129 & & \\
\hline \multirow[t]{2}{*}{268} & gi|322702591 & 39769 & 5.53 & 20 & $34 \%$ & 109 & \multirow[t]{2}{*}{$\begin{array}{l}\text { cyanide hydratase [Metarhizium anisopliae ARSEF 23] } \\
\text { cyanide hydratase [Metarhizium anisopliae] }\end{array}$} & \multirow[t]{2}{*}{$\begin{array}{l}\text { [cd07564] nitrilases, cyanide hydratase }(\mathrm{CH}) \mathrm{s} \text {, and similar } \\
\text { proteins (class } 1 \text { nitrilases); } \mathrm{E}=2.75 \mathrm{e}-119\end{array}$} \\
\hline & gi|88766405 & 39768 & 5.63 & 20 & $34 \%$ & 109 & & \\
\hline 275 & gi|346322842 & 42559 & & & & 68 & $\begin{array}{l}\text { vacuolar protease A precursor [Cordyceps militaris } \\
\text { CM01] }\end{array}$ & $\begin{array}{l}\text { [cd05471] pepsin-like aspartic proteases; } E=3.95 e-97 \\
\text { [pfam00026] eukaryotic aspartyl protease; } E=1.54 \mathrm{e}-119\end{array}$ \\
\hline \multirow[t]{3}{*}{285} & gi|225559211 & 36835 & 8.26 & 16 & $28 \%$ & 80 & \multirow{3}{*}{$\begin{array}{l}\text { NADP-dependent glycerol dehydrogenase [Ajellomyces } \\
\text { capsulatus G186AR] } \\
\text { aldehyde reductase I [Ajellomyces dermatitidis } \\
\text { SLH14081] } \\
\text { aldehyde reductase I [Ajellomyces dermatitidis ER-3] }\end{array}$} & \multirow[t]{3}{*}{ [cd06660] aldo-keto reductases; $E=7.51 \mathrm{e}-78$} \\
\hline & gi|261204493 & 37322 & 6.28 & 15 & $30 \%$ & 80 & & \\
\hline & gi|239614213 & 37350 & 6.43 & 15 & $29 \%$ & 80 & & \\
\hline \multirow[t]{3}{*}{286} & gi|429862698 & 36234 & 6.25 & 33 & $55 \%$ & 366 & \multirow{3}{*}{$\begin{array}{l}\text { glyceraldehyde-3-phosphate dehydrogenase } \\
\text { [Colletotrichum gloeosporioides Nara gc5] } \\
\text { glyceraldehyde-3-phosphate dehydrogenase } \\
\text { [Colletotrichum gloeosporioides Cg-14] } \\
\text { glyceraldehyde-3-phosphate dehydrogenase } \\
\text { [Colletotrichum orbiculare MAFF 240422] }\end{array}$} & $\begin{array}{l}\text { [pfam02800] glyceraldehyde 3-phosphate dehydrogenase, C- } \\
\text { terminal domain; } E=7.93 \mathrm{e}-100\end{array}$ \\
\hline & gi|530477121 & 36248 & 6.25 & 31 & $55 \%$ & 335 & & $\begin{array}{l}\text { [pfam00044] glyceraldehyde 3-phosphate dehydrogenase, NAD } \\
\text { binding domain; } E=9.57 e-80\end{array}$ \\
\hline & gi|477536372 & 36232 & 6.24 & 30 & $51 \%$ & 333 & & $\begin{array}{l}\text { [COG0057] glyceraldehyde-3-phosphate } \\
\text { dehydrogenase/erythrose-4-phosphate dehydrogenase; } \\
\mathrm{E}=0 \mathrm{e}+00\end{array}$ \\
\hline 295 & gi|302884358 & 39125 & 5.24 & 13 & $27 \%$ & 139 & $\begin{array}{l}\text { fructose-bisphosphate aldolase [Nectria haematococca } \\
\mathrm{mpVI} 77-13-4 \text { ] }\end{array}$ & $\begin{array}{l}\text { [PRK09197] fructose-bisphosphate aldolase; Provisional; } \\
E=0 e+00\end{array}$ \\
\hline & gi|342871910 & 37275 & 5.24 & 10 & $21 \%$ & 127 & $\begin{array}{l}\text { hypothetical protein FOXB_15150 [Fusarium oxysporum } \\
\text { Fo5176] }\end{array}$ & $\begin{array}{l}\text { [Superfamily] cl17181, fructose/tagarose-bisphosphate aldolase } \\
\text { class II }\end{array}$ \\
\hline & gi|475673861 & 39633 & 5.44 & 10 & $20 \%$ & 127 & $\begin{array}{l}\text { Fructose-bisphosphate aldolase [Fusarium oxysporum f. } \\
\text { sp. cubense race 4] }\end{array}$ & \\
\hline 304 & gi|389747275 & 123885 & & & & 30 & $\begin{array}{l}\text { hypothetical protein STEHIDRAFT_167739 [Stereum } \\
\text { hirsutum FP-91666 SS1] }\end{array}$ & No match \\
\hline 307 & $\begin{array}{l}\text { gi|322697295 } \\
\text { gi|322712191 }\end{array}$ & $\begin{array}{l}35337 \\
34600\end{array}$ & $\begin{array}{l}6.49 \\
6.86\end{array}$ & $\begin{array}{l}38 \\
35\end{array}$ & $\begin{array}{l}51 \% \\
44 \%\end{array}$ & $\begin{array}{l}207 \\
195\end{array}$ & $\begin{array}{l}\text { transaldolase [Metarhizium acridum CQMa 102] } \\
\text { transaldolase [Metarhizium anisopliae ARSEF 23] }\end{array}$ & $\begin{array}{l}\text { [cd00957] transaldolases including both TalA and TalB; } \\
E=2.63 e-176\end{array}$ \\
\hline & gi|531856223 & 35087 & 6.86 & 34 & $49 \%$ & 194 & Transaldolase [Ophiocordyceps sinensis CO18] & $\begin{array}{l}\text { [PTZ00411] transaldolase-like protein; Provisional; E=5.88e- } \\
152\end{array}$ \\
\hline 311 & gi|322697295 & 35337 & 6.49 & 30 & $39 \%$ & 76 & transaldolase [Metarhizium acridum CQMa 102] & [cd00957] transaldolases including both TalA and TalB; \\
\hline & $\begin{array}{l}\text { gi } \mid 322712191 \\
\text { gi|399165577 }\end{array}$ & $\begin{array}{l}34600 \\
35653\end{array}$ & $\begin{array}{l}6.86 \\
5.64\end{array}$ & $\begin{array}{l}28 \\
23\end{array}$ & $\begin{array}{l}41 \% \\
29 \%\end{array}$ & $\begin{array}{l}76 \\
76\end{array}$ & $\begin{array}{l}\text { transaldolase [Metarhizium anisopliae ARSEF 23] } \\
\text { probable transaldolase [Claviceps purpurea 20.1] }\end{array}$ & $\begin{array}{l}\mathrm{E}=2.63 \mathrm{e}-176 \\
\text { [PTZ00411] transaldolase-like protein; Provisional; } E=5.88 \mathrm{e}-\end{array}$ \\
\hline 313 & gi|336464274 & 39807 & & & & 43 & $\begin{array}{l}\text { mitochondrial Cytochrome c peroxidase [Neurospora } \\
\text { tetrasperma FGSC 2508] }\end{array}$ & No match \\
\hline 314 & gi|67539148 & 30223 & 4.85 & 16 & $28 \%$ & 161 & $\begin{array}{l}\text { hypothetical protein AN5744.2 [Aspergillus nidulans } \\
\text { FGSC A4] }\end{array}$ & $\begin{array}{l}\text { [cd11309] fungal 14-3-3 protein domain; E=2.80e-138 } \\
\text { [Superfamily] cl02098, 14-3-3 domain }\end{array}$ \\
\hline & gi|46108718 & 27506 & 4.94 & 14 & $22 \%$ & 161 & $\begin{array}{l}\text { hypothetical protein FG01241.1 [Fusarium graminearum } \\
\mathrm{PH}-1 \text { ] }\end{array}$ & \\
\hline & gi|70991439 & 30085 & 4.74 & 16 & $35 \%$ & 161 & 14-3-3 family protein [Aspergillus fumigatus Af293] & \\
\hline $\begin{array}{l}323 / \\
4\end{array}$ & gi|302654183 & 20680 & 4.83 & 15 & $20 \%$ & 202 & $\begin{array}{l}\text { conserved hypothetical protein [Trichophyton } \\
\text { verrucosum HKI 0517] }\end{array}$ & [PRK12678] transcription termination factor Rho; Provisional; \\
\hline & gi|530473648 & 32195 & 4.45 & 20 & $47 \%$ & 187 & $\begin{array}{l}\text { hypothetical protein CGLO_06169 [Colletotrichum } \\
\text { gloeosporioides Cg-14] }\end{array}$ & $\begin{array}{l}\text { [PRK08581] N-acetylmuramoyl-L-alanine amidase; Validated; } \\
E=0.03\end{array}$ \\
\hline & gi|261196113 & 40526 & 6.85 & 32 & $46 \%$ & 186 & $\begin{array}{l}\text { mold-specific protein [Ajellomyces dermatitidis } \\
\text { SLH14081] }\end{array}$ & \\
\hline 325 & gi|451845560 & 86771 & & & & 46 & $\begin{array}{l}\text { hypothetical protein COCSADRAFT_165126 [Bipolaris } \\
\text { sorokiniana ND90Pr] }\end{array}$ & No match \\
\hline 344 & gi|465796311 & 66213 & & & & 39 & $\begin{array}{l}\text { unnamed protein product [Malassezia sympodialis } \\
\text { ATCC 42132] }\end{array}$ & No match \\
\hline 384 & gi|401888325 & 27630 & 7.64 & 15 & $40 \%$ & 75 & $\begin{array}{l}\text { L-xylulose reductase [Trichosporon asahii var. asahii } \\
\text { CBS 2479] }\end{array}$ & $\begin{array}{l}\text { [cd05352] mannitol dehydrogenase (MDH)-like, classical (c) } \\
\text { SDRs; E=1.03e-119 } \\
\text { [PRK05557] 3-ketoacyl-(acyl-carrier-protein) reductase; }\end{array}$ \\
\hline
\end{tabular}




\begin{tabular}{|c|c|c|c|c|c|c|c|c|}
\hline & & & & & & & & Validated; $E=1.81 e-52$ \\
\hline 391 & gi|399170748 & 23636 & & & & 36 & $\begin{array}{l}\text { probable MET14-ATP adenosine-5'-phosphosulfate } 3{ }^{`} \text { - } \\
\text { phosphotransferase [Claviceps purpurea 20.1] }\end{array}$ & No match \\
\hline 392 & gi|242210763 & 153303 & & & & 34 & predicted protein [Postia placenta Mad-698-R] & No match \\
\hline \multirow[t]{3}{*}{396} & gi|346327419 & 26911 & 6.02 & 14 & $32 \%$ & 139 & \multirow{3}{*}{$\begin{array}{l}\text { triosephosphate isomerase [Cordyceps militaris CM01] } \\
\text { triosephosphate isomerase [Arthroderma gypseum CBS } \\
\text { 118893] } \\
\text { hypothetical protein SCHCODRAFT_71461 } \\
\text { [Schizophyllum commune } \mathrm{H} 4-8 \text { ] }\end{array}$} & \multirow[t]{3}{*}{ [cd00311] triosephosphate isomerase (TIM); $E=8.40 \mathrm{e}-111$} \\
\hline & gi|315042127 & 27047 & 5.59 & 12 & $30 \%$ & 110 & & \\
\hline & gi|302672679 & 26429 & 6.10 & 6 & $10 \%$ & 104 & & \\
\hline 417 & gi|310791594 & 19059 & & & & 61 & $\begin{array}{l}\text { hypothetical protein GLRG_02292 [Colletotrichum } \\
\text { graminicola M1.001] }\end{array}$ & No match \\
\hline 423 & gi|46124419 & 23107 & & & & 72 & $\begin{array}{l}\text { RS7_NEUCR 40S ribosomal protein S7 [Fusarium } \\
\text { graminearum } \mathrm{PH}-1 \text { ] }\end{array}$ & [pfam01251] ribosomal protein S7e; E=5.11e-101 \\
\hline 426 & gi|322707797 & 24900 & & & & 65 & $\begin{array}{l}\text { manganese superoxide dismutase [Metarhizium } \\
\text { anisopliae ARSEF 23] }\end{array}$ & $\begin{array}{l}\text { [pfam02777] iron/manganese superoxide dismutases, C- } \\
\text { terminal domain; } E=1.25 \mathrm{e}-50 \\
\text { (super family) cl02809; } E=1.92 \mathrm{e}-33 \\
\text { [COG0605] superoxide dismutase; } E=7.09 \mathrm{e}-90\end{array}$ \\
\hline 445 & gi|340518075 & 18835 & & & & 47 & acetyltransferase [Trichoderma reesei QM6a] & No match \\
\hline 446 & gi|361124833 & 21389 & & & & 53 & $\begin{array}{l}\text { putative Peptidyl-prolyl cis-trans isomerase, } \\
\text { mitochondrial [Glarea lozoyensis 74030] }\end{array}$ & No match \\
\hline 460 & $\begin{array}{l}\text { gi } \mid 340518820 \\
\text { gi|358385634 } \\
\text { gi } \mid 51701481\end{array}$ & $\begin{array}{l}14822 \\
14836 \\
14789\end{array}$ & $\begin{array}{l}10.12 \\
10.12 \\
10.16\end{array}$ & $\begin{array}{l}16 \\
16 \\
14\end{array}$ & $\begin{array}{l}48 \% \\
48 \% \\
42 \%\end{array}$ & $\begin{array}{l}86 \\
86 \\
86\end{array}$ & $\begin{array}{l}\text { histone H2B [Trichoderma reesei QM6a] } \\
\text { hypothetical protein TRIVIDRAFT_92198 [ Trichoderma } \\
\text { virens Gv29-8] } \\
\text { RecName: Full=Histone H2B }\end{array}$ & $\begin{array}{l}\text { [smart00427] histone } \mathrm{H} 2 \mathrm{~B} ; \mathrm{E}=4.30 \mathrm{e}-49 \\
\text { [Superfamily] cl00074, histone } \mathrm{H} 4\end{array}$ \\
\hline 488 & gi|169866979 & 38595 & & & & 32 & $\begin{array}{l}\text { hypothetical protein CC1G_12126 [Coprinopsis cinerea } \\
\text { okayama7\#130] }\end{array}$ & No match \\
\hline 496 & $\begin{array}{l}\text { gi } \mid 340519078 \\
\text { gi } \mid 322708039\end{array}$ & $\begin{array}{l}12201 \\
11859\end{array}$ & $\begin{array}{l}4.72 \\
5.02\end{array}$ & $\begin{array}{l}7 \\
7\end{array}$ & $\begin{array}{l}23 \% \\
57 \%\end{array}$ & $\begin{array}{l}82 \\
81\end{array}$ & $\begin{array}{l}\text { predicted protein [ Trichoderma reesei QM6a] } \\
\text { phosphoglycerate mutase family protein, putative } \\
\text { [Metarhizium anisopliae ARSEF 23] }\end{array}$ & [DUF3759] protein of unknown function; $E=1.93 e-35$ \\
\hline & gi|531861288 & 11406 & 5.87 & 4 & $33 \%$ & 81 & $\begin{array}{l}\text { hypothetical protein OCS_04883 [Ophiocordyceps } \\
\text { sinensis CO18] }\end{array}$ & \\
\hline 501 & gi|354548424 & 10273 & & & & 38 & $\begin{array}{l}\text { hypothetical protein CPAR2_701720 [Candida } \\
\text { parapsilosis] }\end{array}$ & No match \\
\hline 504 & gi|449548976 & 97320 & & & & 37 & $\begin{array}{l}\text { hypothetical protein CERSUDRAFT_ } 81259 \\
\text { [Ceriporiopsis subvermispora B] }\end{array}$ & No match \\
\hline 507 & gi|401888325 & 27630 & & & & 48 & $\begin{array}{l}\text { L-xylulose reductase [ Trichosporon asahii var. asahii } \\
\text { CBS 2479] }\end{array}$ & No match \\
\hline 509 & gi|389747275 & 123885 & & & & 29 & $\begin{array}{l}\text { hypothetical protein STEHIDRAFT_167739 [Stereum } \\
\text { hirsutum FP-91666 SS1] }\end{array}$ & No match \\
\hline 510 & gi|85096905 & 104082 & & & & 36 & $\begin{array}{l}\text { hypothetical protein NCU07082 [Neurospora crassa } \\
\text { OR74A] }\end{array}$ & No match \\
\hline 514 & gi|465796311 & 66213 & & & & 39 & $\begin{array}{l}\text { unnamed protein product [Malassezia sympodialis } \\
\text { ATCC 42132] }\end{array}$ & No match \\
\hline 518 & gi|388851491 & 17286 & & & & 39 & $\begin{array}{l}\text { probable ribosomal protein L24.e.A, cytosolic [Ustilago } \\
\text { hordel] }\end{array}$ & No match \\
\hline 524 & gi|449548609 & 174362 & & & & 39 & $\begin{array}{l}\text { hypothetical protein CERSUDRAFT_111891 } \\
\text { [Ceriporiopsis subvermispora B] }\end{array}$ & No match \\
\hline 528 & gi|240278303 & 134994 & & & & 45 & p150 dynactin NUDM [Ajellomyces capsulatus H143] & No match \\
\hline
\end{tabular}

